\title{
The Effect of $\mathrm{HCl}$ and Steam on Cyclic $\mathrm{CO}_{2}$ Capture Performance in Calcium Looping Systems
}

\author{
Robert T. Symonds ${ }^{a}$, Dennis Y. Lu ${ }^{a}$, Arturo Macchi ${ }^{b}$, Robin W. Hughes ${ }^{a}$, Edward J. Anthony $^{c}$
}

\author{
${ }^{a}$ Natural Resources Canada, CanmetENERGY, 1 Haanel Drive, Ottawa, Ontario K1A 1M1, Canada \\ ${ }^{\mathrm{b}}$ Department of Chemical and Biological Engineering, University of Ottawa, 161 Louis Pasteur Street, \\ Ottawa, Ontario K1N 6N5, Canada \\ 'Centre for Combustion, Carbon Capture and Storage, Cranfield University, Cranfield, Bedfordshire MK43 \\ OAL, United Kingdom
}

*Corresponding author: Tel. +1-613-996-2760;

E-mail address: Dennis.Lu@canada.ca

\section{Highlights}

- The effect of $\mathrm{HCl}$ and steam addition during carbonation and calcination using a Canadian limestone was investigated.

- The experiments were conducted using thermogravimetric analysis and fixed bed reactor testing.

- The presence of $\mathrm{HCl}$ was found to increase sorbent reactivity towards $\mathrm{CO}_{2}$ capture when steam was injected during calcination.

- Full sorbent dechlorination can be expected under typical oxy-fuel calcination conditions.

- The decomposition of $\mathrm{CaCl}_{2}$ to $\mathrm{CaO}$ during calcination caused changes in the particle morphology, which in turn decreased the $\mathrm{CO}_{2}$ diffusional resistance during carbonation.

\section{Abstract}

Calcium looping is $\mathrm{CO}_{2}$ capture technology that is considered to be technically feasible at an industrial scale using a variety of fuels such as natural gas, coals, biomass, refuse derived fuels, and biofuels. Unfortunately, many of these fuels contain significant quantities of chlorine which principally converts to gaseous $\mathrm{HCl}$ during combustion or gasification. To date, very few studies have examined the 
effect of $\mathrm{HCl}$ on sorbent $\mathrm{CO}_{2}$ capture performance using calcium-based sorbents under realistic carbonation and calcination conditions. In this work, experiments were conducted using thermogravimetric analysis and fixed bed reactor testing to determine the effect of $\mathrm{HCl}$ addition during carbonation and calcination over repeated cycles using a Canadian limestone. The presence of $\mathrm{HCl}$ was found to increase sorbent reactivity towards $\mathrm{CO}_{2}$ capture when steam was injected during calcination. The resulting decomposition of $\mathrm{CaCl}_{2}$ to $\mathrm{CaO}$ during calcination caused changes in the particle morphology, which in turn decreased the $\mathrm{CO}_{2}$ diffusional resistance during carbonation. Fixed bed test results provided confirmation of full sorbent dechlorination under typical oxy-fuel calcination conditions. It was shown that both particle surface area and pore volume were higher during tests where $\mathrm{HCl}$ was present during carbonation and that greater than $99 \% \mathrm{HCl}$ capture could be achieved without adversely affecting sorbent $\mathrm{CO}_{2}$ capture performance when steam was present during both carbonation and calcination.

Keywords: $\mathrm{CO}_{2}$ capture, $\mathrm{HCl}$ capture, calcium looping, calcium based sorbent 


\section{Introduction}

$\mathrm{CO}_{2}$ emissions from fossil-fuelled power stations are believed to be a major contributor to global warming and climate change (Pachauri \& Reisinger, 2007) (IEA, 2010). One method for reducing $\mathrm{CO}_{2}$ emissions would be via a carbon capture, utilization, and storage (CCUS) technology (Boot-Handford, et al., 2014). The rationale for the use of CCS on fossil-fuelled power plants is that, when deployed with other technologies (e.g., renewables), the overall cost of electricity would be minimized. Since the use of renewable sources of electricity (e.g., wind, solar, etc.) are intermittent, the implementation of CCS to fossil-fueled power plants would reduce the need for large-scale energy storage systems (IEA, 2014) (Fennell \& Anthony, 2015). To date, many methods for $\mathrm{CO}_{2}$ capture have been investigated (Abu-Zahra, Schneiders, Niederer, Feron, \& Versteeg, 2007) (Elwell \& Grant, 2006) (Fauth, Frommell, Hoffman, Reasbeck, \& Pennline, 2005) (Resnik, Yeh, \& Pennline, 2004) (Wall, Stanger, \& Santos, 2011) (Yang, et al., 2008) (Hack, et al., 2012) (Suraniti, Nsakala, \& Darling, 2009) (Ryden \& Lyngfelt, 2006), with calcium looping emerging as one of the most promising technologies for large-scale industrial applications.

The calcium looping process is based on the reversible reaction between $\mathrm{CaO}$ and $\mathrm{CO}_{2}$ (Shimizu, et al., 1999) and utilizes a dual-fluidized bed reactor system. CFB and/or BFB systems are particularly suited from processing large quantities of solids and reactions between gas and solid streams are significantly enhanced by superior mixing that maximizes mass and heat transfer (Davidson, Clift, \& Harrision, 1985). Therefore, at appropriate temperatures and pressures, a flue gas stream can be decarbonized by being passed through a fluidized bed of calcined limestone or dolomite $(\mathrm{CaO})$ to form $\mathrm{CaCO}_{3}$ (carbonation, Equation 1). The carbonated material is then transferred to a second fluidized bed (calciner) where, at higher temperatures and/or lower pressures, the calcination reaction occurs (Equation 2). The resulting gas stream is concentrated $\mathrm{CO}_{2}(>90 \%)$, which is then suitable for liquefaction and ultimate sequestration. The heat of regeneration is supplied by the combustion of a fuel, such as coal or biomass, with high purity $\mathrm{O}_{2}$ and a diluent; recycle flue gas or steam. The calciner is operated as an oxy-fuel CFBC and the high temperature utilized for regeneration allows for the production of high quality steam for electrical power generation.

$\mathrm{CaO}(\mathrm{s})+\mathrm{CO}_{2}(\mathrm{~g}) \rightarrow \mathrm{CaCO}_{3}(\mathrm{~s})$

$\mathrm{CaCO}_{3}(\mathrm{~s}) \rightarrow \mathrm{CaO}(\mathrm{s})+\mathrm{CO}_{2}(\mathrm{~g})$

Calcium looping is considered to be technically feasible at an industrial scale (Fennell \& Anthony, 2015) (Sanchez-Biezma, et al., 2013) (Blamey, Anthony, Wang, \& Fennell, 2010) (Yang, et al., 2010), relatively energy-efficient (Ball, 2014) (Goto, Yogo, \& Higashii, 2013) (Lara, Lisbona, Martinez, \& Romeo, 2013) (Martinez, Lara, Lisbona, \& Romeo, 2012) (Rodriguez, Alonso, Grasa, \& Abanades, 2008), economically competitive (MacKenzie, Granatstein, Anthony, \& Abanades, 2007) (Abanades, et al., 2007) (Abanades, Rubin, \& Anthony, 2004), and environmentally benign because of the relatively inert nature of the solid residues produced by the process. Moreover, the spent residues could also be used in cement manufacturing or other industrial processes (Dean, Dugwell, \& Fennell, 2011) (Dean, Blamey, Florin, Al-Jeboori, \& Fennell, 2011) (Rodriguez, Murillo, \& Abanades, 2012) (Romeo, Catalina, Lisbona, Lara, \& Martinez, 2011).

Many bench-scale studies have demonstrated that naturally occurring limestone sorbents exhibit a rapid decay in $\mathrm{CO}_{2}$ capture reactivity with increasing calcination/carbonation cycle number attributed mainly to thermal sintering of the particles (Grasa \& Abanades, 2006) (Chrissafis, 2007) 
(Wang, Manovic, Wu, \& Anthony, 2010). Due to the adverse effect of sorbent deactivation on the overall process efficiency, intensive research has been focused on $\mathrm{CaO}$ reactivation methods and the development of routes to obtain more stable $\mathrm{CaO}$-based $\mathrm{CO}_{2}$ sorbents (Kierzkowska, Pacciani, \& Muller, 2013) (Valverde, Sanchez-Jimenez, \& Perez-Maqueda, 2014). Some of the more researched methods include steam reactivation (Arias, Grasa, \& Abanades, 2010) (Fennell, Davidson, Dennis, \& Hayhurst, 2007) (Hughes, Lu, Anthony, \& Wu, 2004) (Manovic \& Anthony, 2007), self-reactivation (Manovic \& Anthony, 2008), sorbent doping (Al-Jeboori, Nguyen, Dean, \& Fennell, 2013), pelletized / synthetic sorbents (Symonds, Champagne, Firas, \& Lu, 2016) (Blamey, Anthony, Wang, \& Fennell, 2010) (Chen, Zhao, Yang, \& Zhang, 2012), and recarbonation (Arias, Grasa, Alonso, \& Abanades, 2012) (Valverde, Sanchez-Jimenez, \& Perez-Maqueda, 2014).

The $\mathrm{CO}_{2}$ carrying capacity of calcium based sorbents is not only reduced by thermal sintering, but also by competitive reactions with other pollutants commonly found in combustion flue gas. One of which is $\mathrm{SO}_{2}$, which at normal combustor operating conditions irreversibly reacts with both $\mathrm{CaO}$ and $\mathrm{CaCO}_{3}$ to form $\mathrm{CaSO}_{4}$, limiting carbonation conversions due to pore blockage (Borgwardt, 1970) (Tullin \& Ljungstrom, 1989) (Sun, Grace, Lim, \& Anthony, 2006) (Arias, Cordero, Alonso, \& Abanades, 2012). Many fuels such as coal, biomass, refuse derived fuel (RDF) and biofuels contain significant quantities of chlorine which principally converts to gaseous $\mathrm{HCl}$ during combustion or gasification. Authors Partanen et al. (2005) and Chyang et al. (2009) suggested that flue gas concentrations of $\mathrm{HCl}$ could reach upwards of 2000 ppm, which requires capture in order to avoid corrosion and fouling of boiler components and other downstream equipment. Calcium-based sorbents are commonly used for $\mathrm{HCl}$ capture in combustion or gasification systems, as shown in Equations 3 and 4.

$\mathrm{CaO}(\mathrm{s})+2 \mathrm{HCl}(\mathrm{g}) \leftrightarrow \mathrm{CaCl}_{2}(\mathrm{~s}, \mathrm{l})+\mathrm{H}_{2} \mathrm{O}(\mathrm{g})$

$\mathrm{CaCO}_{3}(\mathrm{~s})+2 \mathrm{HCl}(\mathrm{g}) \leftrightarrow \mathrm{CaCl}_{2}(\mathrm{~s}, \mathrm{l})+\mathrm{H}_{2} \mathrm{O}(\mathrm{g})+\mathrm{CO}_{2}(\mathrm{~g})$

It has been shown that the optimum $\mathrm{HCl}$ capture capacity using $\mathrm{CaO}$ is achieved in the temperature range of $500-650^{\circ} \mathrm{C}$ (Bie, Li, \& Yang, 2005) (Chyang, Han, \& Zhong, 2009), with the highest capture capacity reported at $550^{\circ} \mathrm{C}$ (Sun, Yu, Li, Li, \& Fan, 2011). Lower conversions reported at temperatures above $800^{\circ} \mathrm{C}$ have been attributed to the formation of molten $\mathrm{CaCl}_{2}$ product phases. Therefore, it would be expected that both $\mathrm{HCl}$ and $\mathrm{CO}_{2}$ capture would occur simultaneously with calcium-based sorbents in the calcium looping process, since typical carbonation temperatures are in the range of $650-720^{\circ} \mathrm{C}$ (Manovic \& Anthony, 2008) (Grasa, Abanades, Alonso, \& Gonzalez, 2008). Several reported investigations have examined the effect of gas atmosphere on $\mathrm{HCl}$ capture by calciumbased sorbents. Partanen et al. (2005) discovered that the presence of $\mathrm{CO}_{2}$ resulted in a higher $\mathrm{HCl}$ capture capacity, although it should be noted that both Duo et al. (1996) and Chin et al. (2005) observed the opposite effect. This decrease in $\mathrm{HCl}$ capture capacity was attributed to an increase in diffusion resistance due to $\mathrm{CO}_{2}$ reacting with $\mathrm{CaO}$ forming $\mathrm{CaCO}_{3}$. Another major species of interest is steam, which would be present during both carbonation and calcination processes associated with calcium looping. The presence of steam has been shown to decrease the $\mathrm{HCl}$ capture capacity of calcium-based sorbents by as much as $50 \%$, with this effect becoming more prominent at higher temperatures $\left(>650^{\circ} \mathrm{C}\right)$ (Lawrence \& Bu, 2000) (Partanen, Backman, Backman, \& Hupa, 2005).

To date, almost all investigations just focus on the effect of $\mathrm{CO}_{2}$ and steam on $\mathrm{HCl}$ capture and do not consider the impact of $\mathrm{HCl}$ on $\mathrm{CO}_{2}$ capture using calcium-based sorbents. In these cases the ultimate goal is to maximize $\mathrm{HCl}$ capture by forming $\mathrm{CaCl}_{2}$, which is subsequently removed from the 
process and not repeatedly cycled as is the case with calcium looping. Wang et al. (2014) addressed this issue by performing multiple calcination/carbonation cycles in the presence of $\mathrm{HCl}$ at various calcination and carbonation conditions. Although this gave significant insight into the effect of $\mathrm{HCl}$ on the calcium looping process as a whole, the presence of steam during calcination and carbonation was not considered. Both calcination and carbonation environments would contain some level of steam, which by examining Equations 3 and 4, should significantly impact the level of $\mathrm{CaCl}_{2}$ formation over repeated cycles. In this present work, the cyclic $\mathrm{CO}_{2}$ capture behavior of limestone in the presence of $\mathrm{HCl}$ during calcination and/or carbonation under more realistic conditions was examined via thermogravimetric analysis (TGA). In addition, fixed bed reactor testing was performed to quantify the level of chlorination/de-chlorination expected in a real dual fluidized bed reactor system.

\section{Experimental Details}

\subsection{Thermogravimetric analyzer (TGA) and fixed bed reactor system}

Figure 1 is a schematic diagram of the thermogravimetric analyzer (TGA) and fixed bed reactor systems used for this experimental test work. The TGA system was comprised of a hang-down tube reactor column made of Inconel 625 alloy with an inner diameter of $0.025 \mathrm{~m}$. Located centrally within the hang-down tube was a platinum sample tray suspended from a Cahn 1000 Electrobalance with a capacity of $100 \mathrm{~g}$ and a sensitivity of $1 \mu \mathrm{g}$. Weight measurements were sent from the balance to the control box, which was controlled by the use of customized Honeywell software. The fixed bed reactor was fabricated out of Hastelloy HT and was outfitted with a $0.013 \mathrm{~m}$ custom ceramic tube insert capable of holding samples of up to $10 \mathrm{~g}$ in size. Samples were held in place via high temperature ceramic meshing.

Gas cylinders containing $\mathrm{N}_{2}, \mathrm{CO}_{2}$, and $\mathrm{HCl}$ (balance $\mathrm{CO}_{2}$ ) were mixed before entering the inlets to both the TGA and fixed bed reactor. Brooks mass flow controllers (0-100 and 500 NmL/min) were used to accurately control the gas flow rates to obtain desired feed gas concentrations. Steam was fed to both systems via a Harvard PHD 440 syringe pump and steam generator. Feed lines containing both steam and mixed gas were insulated and electrically heat-traced to ensure no steam condensation occurred. A purge gas ( $N_{2}$ in all cases) was top-fed through the balance of the TGA to ensure the sensitive balance electronics did not overheat and that the reaction gases did not enter the balance housing. Purge gas was fed to the outlet of the fixed bed reactor for sample gas dilution. Outlet gases from both systems were subsequently cooled, to condense steam, passed through a moisture trap, and finally vented to the atmosphere. Both reactors were heated by means of electric heaters located centrally around the sample holders and can reach temperatures up to $950^{\circ} \mathrm{C}$. System temperatures were monitored using K-type thermocouples, as shown in Figure 1. Honeywell software was used to control all gas flow rates, electric heaters, and heat-tracing and was operated in automatic mode to allow for changes in operating condition set points. All temperatures, flow rates, and weight measurements were recorded every $6 s$ and stored in Microsoft Excel files. During fixed bed reactor testing, a portable GASMET Fourier transform infrared (FTIR) spectrometer was employed to measure the outlet gas composition $\left(\mathrm{CO}_{2}, \mathrm{H}_{2} \mathrm{O}\right.$, and $\left.\mathrm{HCl}\right)$. 


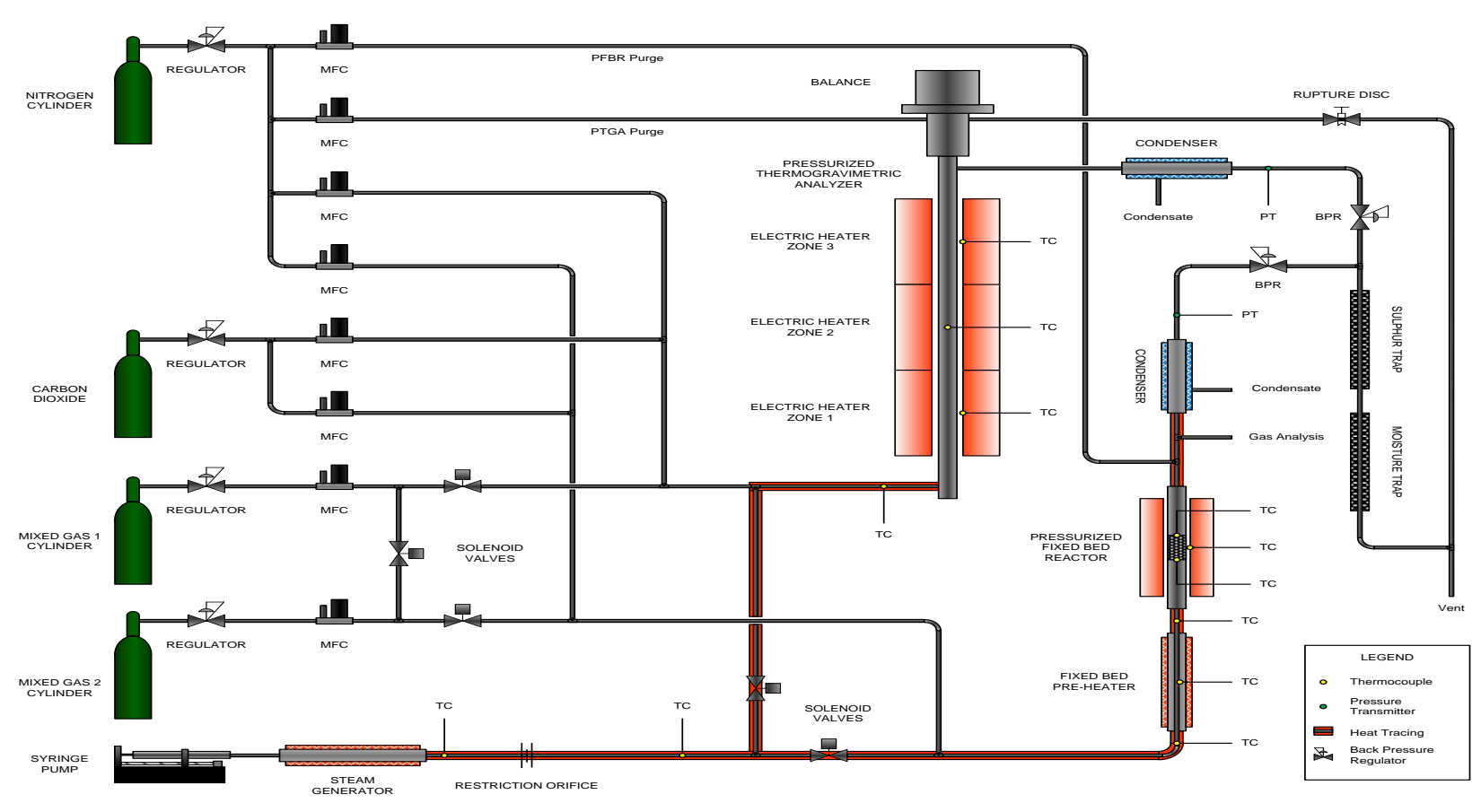

Figure 1: Schematic diagram of the TGA and fixed bed reactor experimental setup.

\subsection{Experimental test conditions}

The $\mathrm{CaO}$ source for all TGA and fixed bed experiments was a naturally occurring Canadian limestone (Cadomin). The limestone was crushed and sieved to a single particle size range of 250 to $425 \mu \mathrm{m}$ in diameter, as this represents a common particle size range used during dual fluidized bed reactor operation (Ridha, Lu, Symonds, \& Champagne, 2016) (Champagne, Lu, Symonds, Macchi, \& Anthony, 2016). Approximately 20 to $25 \mathrm{mg}$ and $5 \mathrm{~g}$ of sorbent were used for TGA and fixed bed reactor experiments, respectively. In the case of the TGA testing, this particular sample size was chosen in order to lower potential variance in chemical composition between runs, as individual particles can display different $\mathrm{CaO} / \mathrm{MgO}$ ratios. Larger fixed bed samples were utilized to allow for post-run SEM/EDX and pore structure analyses.

To determine the effect of $\mathrm{HCl}$ on the $\mathrm{CO}_{2}$ capture behavior of limestone, experiments were performed with and without $\mathrm{HCl}$ present during both carbonation and calcination over repeated cycles. The rationale is that if an existing power generation facility utilizing a high chlorine fuel is retrofitted for post-combustion $\mathrm{CO}_{2}$ capture using calcium looping, the same fuel would most likely be adopted as the heat source for sorbent regeneration, since the fuel is already on-site. Since the flue gas entering the carbonator would contain some level of steam, its impact on $\mathrm{CO}_{2}$ capture and chlorination was also tested, both with and without $\mathrm{HCl}$ present. In each case, steam was present during calcination as would be the case in any real combustion system, except for two runs where a comparison with a pure $\mathrm{N}_{2}$ environment was performed. For all TGA tests, a total gas flow rate of $100 \mathrm{NmL} / \mathrm{min}$ of reaction gas was used and all tests were performed at atmospheric pressure. Based on previous testing, it has been shown that these conditions limit gas diffusion limitations from the bulk gas to the particle surface (Symonds, Lu, Macchi, Hughes, \& Anthony, 2009). The total gas flow rate was increased to 200 
$\mathrm{NmL} / \mathrm{min}$ for fixed bed reactor tests (1) to achieve a relatively quick $\mathrm{CO}_{2}$ breakthrough and (2) to provide enough sample gas to facilitate the usage of the portable FTIR spectrometer.

As determined by Garcia-Lablano et al. (2002), the equilibrium partial pressure of $\mathrm{CO}_{2}, P_{\mathrm{CO}_{2}, e q}$, over $\mathrm{CaO}$ at a temperature, $T$, is given by the following equation:

$P_{\mathrm{CO}_{2}, \text { eq }}=4.137 \times 10^{12} \exp \left(-\frac{20474}{T}\right)$

Based on Equation 5, the minimum temperature to allow for calcination of the sorbent was determined. It was decided to operate at a temperature slightly higher than equilibrium to ensure a rapid and complete calcination. Carbonation was performed at $650^{\circ} \mathrm{C}$ for all tests, since it has been determined to be the preferred temperature for $\mathrm{CO}_{2}$ capture using calcium-based sorbents (Manovic \& Anthony, 2008) and represents a greater than $90 \% \mathrm{CO}_{2}$ capture efficiency based on a typical coal-combustion flue gas composition ( 15 vol\%). The specific experimental conditions for all TGA and fixed bed reactor tests are presented in Table 1 and Table 2, respectively.

Table 1: Experimental conditions - TGA tests.

\begin{tabular}{|c|c|c|c|}
\hline $\begin{array}{l}\text { Run } \\
\text { No. }\end{array}$ & Carbonation Conditions & Calcination Conditions & $\begin{array}{l}\text { Number } \\
\text { of Cycles }\end{array}$ \\
\hline 1 & 20 mins, $650^{\circ} \mathrm{C}, 15 \mathrm{~mol} \% \mathrm{CO}_{2} /$ balance $\mathrm{N}_{2}$ & 10 mins, $870^{\circ} \mathrm{C}, 100 \mathrm{~mol} \% \mathrm{~N}_{2}$ & 10 \\
\hline 2 & $\begin{array}{l}20 \text { mins, } 650^{\circ} \mathrm{C}, 15 \mathrm{~mol} \% \mathrm{CO}_{2} / 2000 \mathrm{ppm} \\
\mathrm{HCl} / \text { balance } \mathrm{N}_{2}\end{array}$ & 10 mins, $870^{\circ} \mathrm{C}, 100 \mathrm{~mol} \% \mathrm{~N}_{2}$ & 10 \\
\hline 3 & 20 mins, $650^{\circ} \mathrm{C}, 15 \mathrm{~mol} \% \mathrm{CO}_{2} /$ balance $\mathrm{N}_{2}$ & $\begin{array}{l}10 \text { mins, } 870{ }^{\circ} \mathrm{C}, 60 \mathrm{~mol}^{\circ} \mathrm{CO}_{2} / 15 \\
\text { mol\% } \mathrm{H}_{2} \mathrm{O} / \text { balance } \mathrm{N}_{2}\end{array}$ & 10 \\
\hline 4 & $\begin{array}{l}20 \text { mins, } 650^{\circ} \mathrm{C}, 15 \mathrm{~mol} \% \mathrm{CO}_{2} / 2000 \mathrm{ppm} \\
\mathrm{HCl} / \text { balance } \mathrm{N}_{2}\end{array}$ & $\begin{array}{l}10 \text { mins, } 870{ }^{\circ} \mathrm{C}, 60 \mathrm{~mol}^{2} \mathrm{CO}_{2} / 15 \\
\text { mol\% } \mathrm{H}_{2} \mathrm{O} / \text { balance } \mathrm{N}_{2}\end{array}$ & 10 \\
\hline 5 & 20 mins, $650^{\circ} \mathrm{C}, 15 \mathrm{~mol} \% \mathrm{CO}_{2} /$ balance $\mathrm{N}_{2}$ & $\begin{array}{l}10 \text { mins, } 870{ }^{\circ} \mathrm{C}, 60 \mathrm{~mol}^{2} \mathrm{CO}_{2} / 15 \\
\text { mol\% } \mathrm{H}_{2} \mathrm{O} / \text { balance } \mathrm{N}_{2}\end{array}$ & 10 \\
\hline 6 & 20 mins, $650^{\circ} \mathrm{C}, 15$ mol\% $\mathrm{CO}_{2} /$ balance $\mathrm{N}_{2}$ & $\begin{array}{l}10 \mathrm{mins}, 870^{\circ} \mathrm{C}, 60 \mathrm{~mol} \% \mathrm{CO}_{2} / 15 \\
\mathrm{~mol} \% \mathrm{H}_{2} \mathrm{O} / 2000 \mathrm{ppm} \mathrm{HCl} / \text { balance } \mathrm{N}_{2}\end{array}$ & 10 \\
\hline 7 & $\begin{array}{l}20 \text { mins, } 650^{\circ} \mathrm{C}, 15 \text { mol\% } \mathrm{CO}_{2} / 15 \text { mol\% } \\
\mathrm{H}_{2} \mathrm{O} / \text { balance } \mathrm{N}_{2}\end{array}$ & $\begin{array}{l}10 \text { mins, } 870{ }^{\circ} \mathrm{C}, 60 \mathrm{~mol}^{\circ} \mathrm{CO}_{2} / 15 \\
\text { mol\% } \mathrm{H}_{2} \mathrm{O} / \text { balance } \mathrm{N}_{2}\end{array}$ & 10 \\
\hline 8 & $\begin{array}{l}20 \text { mins, } 650^{\circ} \mathrm{C}, 15 \text { mol\% } \mathrm{CO}_{2} / 15 \text { mol\% } \\
\mathrm{H}_{2} \mathrm{O} / 2000 \mathrm{ppm} \mathrm{HCl} / \text { balance } \mathrm{N}_{2}\end{array}$ & $\begin{array}{l}10 \text { mins, } 870{ }^{\circ} \mathrm{C}, 60 \text { mol\% } \mathrm{CO}_{2} / 15 \\
\text { mol\% } \mathrm{H}_{2} \mathrm{O} / \text { balance } \mathrm{N}_{2}\end{array}$ & 10 \\
\hline
\end{tabular}

Table 2: Experimental conditions - fixed bed reactor tests.

\begin{tabular}{|c|c|c|c|}
\hline $\begin{array}{l}\text { Run } \\
\text { No. }\end{array}$ & Carbonation Conditions & Calcination Conditions & $\begin{array}{l}\text { Number } \\
\text { of Cycles }\end{array}$ \\
\hline 1 & 20 mins, $650^{\circ} \mathrm{C}, 15 \mathrm{~mol} \% \mathrm{CO}_{2} /$ balance $\mathrm{N}_{2}$ & $\begin{array}{l}20 \text { mins, } 870^{\circ} \mathrm{C}, 60 \mathrm{~mol}^{2} \mathrm{CO}_{2} / 15 \\
\mathrm{~mol}^{2} \mathrm{H}_{2} \mathrm{O} / \text { balance } \mathrm{N}_{2}\end{array}$ & 6 \\
\hline 2 & $\begin{array}{l}20 \text { mins, } 650^{\circ} \mathrm{C}, 15 \mathrm{~mol} \% \mathrm{CO}_{2} / 2000 \mathrm{ppm} \\
\mathrm{HCl} / \text { balance } \mathrm{N}_{2}\end{array}$ & $\begin{array}{l}20 \text { mins, } 870^{\circ} \mathrm{C}, 60 \mathrm{~mol}^{\circ} \mathrm{CO}_{2} / 15 \\
\text { mol\% } \mathrm{H}_{2} \mathrm{O} / \text { balance } \mathrm{N}_{2}\end{array}$ & 6 \\
\hline 3 & $\begin{array}{l}20 \text { mins, } 650^{\circ} \mathrm{C}, 15 \text { mol\% } \mathrm{CO}_{2} / 15 \mathrm{~mol} \% \\
\mathrm{H}_{2} \mathrm{O} / \text { balance } \mathrm{N}_{2}\end{array}$ & $\begin{array}{l}20 \text { mins, } 870^{\circ} \mathrm{C}, 60 \mathrm{~mol}^{\circ} \mathrm{CO}_{2} / 15 \\
\mathrm{~mol} \mathrm{H}_{2} \mathrm{O} / \text { balance } \mathrm{N}_{2}\end{array}$ & 6 \\
\hline 4 & 20 mins, $650^{\circ} \mathrm{C}, 15 \mathrm{~mol} \% \mathrm{CO}_{2} / 15 \mathrm{~mol} \%$ & 20 mins, $870^{\circ} \mathrm{C}, 60 \mathrm{~mol} \% \mathrm{CO}_{2} / 15$ & 6 \\
\hline
\end{tabular}


For the set of TGA experiments, the carbonation conversion was calculated based on the level of mass change recorded during the calcination step for each cycle, which assumes that all decreases in mass were attributed to the decomposition of $\mathrm{CaCO}_{3}$ to $\mathrm{CaO}$ (Equation 2). It should be noted that all carbonation conversions were determined based on the mass change after 20 min of carbonation. Therefore, the carbonation conversion for each cycle, $X_{\text {carb }, N}$, was calculated as follows:

$X_{C a r b, N}=\frac{m_{c a r b, N}-m_{c a l c, N}}{m_{0} \cdot \beta} \cdot \frac{M_{C a O}}{M_{C O_{2}}} \cdot 100$

where $N$ is the carbonation / calcination cycle number, $m_{\text {carb }}$ is the mass of sample after carbonation, $m_{\text {calc }}$ is the mass of sample after calcination, $m_{0}$ is the initial sample mass, $\beta$ is the content of $\mathrm{CaO}$ in the initial sample, $\mathrm{M}_{\mathrm{CaO}}$ is the molar mass of $\mathrm{CaO}$, and $\mathrm{M}_{\mathrm{CO}_{2}}$ is the molar mass of $\mathrm{CO}_{2}$. Since the melting point of anhydrous $\mathrm{CaCl}_{2}$ is between $772-775^{\circ} \mathrm{C}$ (Pradyot, 2003), any carbonation conditions that form $\mathrm{CaCl}_{2}$ would have the potential for evaporation and sublimation during calcination. A series of preliminary tests were conducted using chlorinated limestone at $870^{\circ} \mathrm{C}$ under an atmospheric pressure $\mathrm{N}_{2}$ environment to quantify the level of $\mathrm{CaCl}_{2}$ evaporation expected during calcination. From these results it was determined that, for such a short calcination period (10 minutes), the level of $\mathrm{CaCl}_{2}$ mass loss was negligible. This outcome is in agreement with the high temperature $\mathrm{HCl}$ absorption work performed by Chyang (2009), which showed a $\mathrm{CaCl}_{2}$ mass loss of less than $0.3 \%$ over a 10 minute period at temperatures similar to this work. Consequently, the chlorination conversion for each cycle, $X_{\text {chlor }, N}$, could be determined via the following equation:

$$
X_{\text {chlor }, N}=\frac{m_{c a l c, N}-m_{0}}{m_{0} \cdot \beta} \cdot \frac{M_{C a O}}{M_{\mathrm{CaCl}_{2}}-M_{\mathrm{CO}_{2}}} \cdot 100
$$

where $\mathrm{M}_{\mathrm{CaCl}_{2}}$ is the molar mass of $\mathrm{CaCl}_{2}$.

The carbonation and chlorination conversions for the fixed bed experiments were calculated using the difference between the measured inlet and outlet flowrates of $\mathrm{CO}_{2}$ and $\mathrm{HCl}$, respectively, over the entire carbonation period, $P_{c a r b}$. Taking into account the initial mass and purity of the sample, the fixed bed conversions for each cycle were determined as follows:

$$
\begin{aligned}
& X_{\text {Carb }, N}=\frac{\left(\text { Mass } \mathrm{CO}_{2} \mathrm{In}-\text { Mass } \mathrm{CO}_{2} \mathrm{Out}\right)}{m_{0} \cdot \beta} \cdot \frac{M_{\mathrm{CaO}}}{M_{\mathrm{CO}_{2}}} \cdot 100 \\
& X_{\text {carb }, N}=\frac{\rho_{\mathrm{CO}_{2}} \cdot\left(\left(F_{\mathrm{CO}_{2}, 0} \cdot P_{\text {carb }}\right)-\left(\int_{t=0}^{t=P_{\text {carb }}} F_{\text {Outlet }} \cdot C_{\mathrm{CO}_{2}}\right)\right)}{m_{0} \cdot \beta} \cdot \frac{M_{\mathrm{CaO}}}{M_{\mathrm{CO}_{2}}} \cdot 100 \\
& X_{\text {chlor }, N}=\frac{\rho_{H C l} \cdot\left(\left(F_{H C l, 0} \cdot P_{c a r b}\right)-\left(\int_{t=0}^{t=P_{\text {carb }}} F_{\text {Outlet }} \cdot C_{H C l}\right)\right)}{m_{0} \cdot \beta} \cdot \frac{M_{C a O}}{2 \cdot M_{H C l}} \cdot 100
\end{aligned}
$$

where $\rho_{\mathrm{CO}_{2}}$ is the density of $\mathrm{CO}_{2}, \rho_{\mathrm{HCl}}$ is the density of $\mathrm{HCl}, \mathrm{F}_{\mathrm{CO}_{2}, 0}$ is the inlet flowrate of $\mathrm{CO}_{2}, \mathrm{~F}_{\mathrm{HCl}, 0}$ is the inlet flowrate of $\mathrm{HCl}, \mathrm{F}_{\text {Outlet }}$ is the total outlet flowrate, $\mathrm{C}_{\mathrm{CO}_{2}}$ is the outlet concentration of $\mathrm{CO}_{2}$, $C_{\mathrm{HCl}}$ is the outlet concentration of $\mathrm{HCl}$, and $\mathrm{M}_{\mathrm{HCl}}$ is the molar mass of $\mathrm{HCl}$. 


\subsection{Thermodynamic equilibrium predictions}

FactSage software predicts equilibrium solid-liquid-gas phases and compositions based on Gibbs free energy minimization (Bale, et al., 2014). Gibbs free energy is calculated from optimized models with parameters based on empirical data with various compositions, temperatures and pressures. This information is contained within compound and solution databases. For thermodynamic equilibrium predictions in this study, the FactSage 6.4 Reaction, Equilib and Phase Diagram modules were utilized with the FactPS and FToxid databases. All gas, liquid and solid compounds were considered. For compounds found in both the FactPS and FToxid databases, preference was given to the FToxid database to have better thermodynamic consistency with the solution phases data. Note that by default some solid and liquid compound phases are not selected and had to be manually selected. All possible solution phases, neglecting immiscibility, were included in the calculations.

\subsection{Sorbent characterization}

Physical and chemical characterizations of the sorbent, before and after testing, were carried out using several different analysis techniques. The composition of the raw sorbent was obtained by $X$ ray fluorescence (XRF) following ASTM D4326 and is provided in Table 3. Specific surface areas and pore volumes were obtained from $\mathrm{N}_{2}$ adsorption measurements at $-196^{\circ} \mathrm{C}$ using a porosity analyzer (Micromeritics TriStar II-3020). Surface area was obtained from adsorption data using the multiple point Brunauer-Emmett-Teller (BET) model, while pore volume was derived from the corresponding desorption data using the Barrett-Joyner-Halenda (BJH) model (Lowell, Thomas, \& Thommes, 2004). The surfaces of particles were examined using a scanning electron microscope (SEM, Hitachi S-3400 N). Localized elemental composition was obtained with energy dispersive X-ray (EDX) spectrometry on the same instrument. For both SEM and EDX analyses, the sample was coated with a thin layer of palladium $(\sim 2 \mathrm{~nm})$.

Table 3: XRF chemical analysis of Cadomin Limestone (wt.\%).

\begin{tabular}{|c|c|c|c|c|c|c|c|c|c|c|}
\hline $\mathrm{CaO}$ & $\mathbf{M g O}$ & $\mathrm{SiO}_{\mathbf{2}}$ & $\mathbf{A l}_{\mathbf{2}} \mathbf{O}_{\mathbf{3}}$ & $\mathbf{F e}_{\mathbf{2}} \mathbf{O}_{\mathbf{3}}$ & $\mathbf{T i O}_{\mathbf{2}}$ & $\mathbf{P}_{\mathbf{2}} \mathbf{O}_{\mathbf{5}}$ & $\mathbf{S O}_{\mathbf{3}}$ & $\mathbf{N a}_{\mathbf{2}} \mathbf{O}$ & $\mathbf{K}_{\mathbf{2}} \mathbf{O}$ & ${ }^{*} \mathrm{LOF}$ \\
\hline 50.64 & 3.28 & 1.30 & 0.40 & 0.11 & 0.04 & $<0.03$ & $<0.1$ & $<0.2$ & 0.14 & 43.99 \\
\hline
\end{tabular}

* LOF $=$ Loss on fusion

\section{Results and Discussion}

\subsection{Effect of $\mathrm{HCl}$ on $\mathrm{CO}_{2}$ capture without the presence of steam}

It is well documented that at temperatures around $650^{\circ} \mathrm{C}$, both carbonation (Equation 1) and chlorination (Equation 3) of $\mathrm{CaO}$ will separately proceed to form $\mathrm{CaCO}_{3}$ and $\mathrm{CaCl}_{2}$, respectively. What is less understood is how the level of conversion of one species will affect the other, how this will affect the rate of $\mathrm{CO}_{2}$ uptake, and what can be expected in terms of cyclic $\mathrm{CO}_{2}$ capture stability over repeated cycles. A preliminary series of tests were conducted to examine the impact of the presence of $\mathrm{HCl}$ on the carbonation conversion over repeated cycles to provide baseline data. In these tests, calcination was performed under pure $\mathrm{N}_{2}$ at $870^{\circ} \mathrm{C}$ and atmospheric pressure to (1) determine the extent of $\mathrm{CaCl}_{2}$ evaporation and (2) compare the cyclic $\mathrm{CO}_{2}$ stability to previous studies.

As indicated above, no measurable level of $\mathrm{CaCl}_{2}$ evaporation was observed over the 20-minute calcination period. This conclusion was based on the fact that after calcination of $\mathrm{CaCO}_{3}$ to $\mathrm{CaO}$ had 
completed, no further weight loss was measured. It should be mentioned that $\mathrm{CaCl}_{2}$ evaporation could have taken place during the calcination period, but this is very unlikely since (1) the calcination reaction was completed within a very short period ( $<2$ minutes) and (2) no $\mathrm{CaCl}_{2}$ deposits were found in the TGA system post-run, which would be expected if evaporation had occurred (Chyang, Han, \& Zhong, 2009).

The carbonation conversions of the Cadomin limestone after repeated cycles in the absence and presence of $\mathrm{HCl}$ are shown in Figure 2. Over all 10 cycles, the carbonation conversions were lower when $\mathrm{HCl}$ was present, with the difference in conversion diminishing with increasing cycle number. From these results, it appears that the formation of $\mathrm{CaCl}_{2}$ on the surface of the $\mathrm{CaO}$ particles increases the $\mathrm{CO}_{2}$ diffusion resistance in comparison to that of $\mathrm{CaCO}_{3}$. This result is quite plausible since the molar volume of $\mathrm{CaCl}_{2}$ is approximately 1.4 times that of $\mathrm{CaCO}_{3}$ (FactSage). It is also important to point out that any $\mathrm{CaCl}_{2}$ formed during carbonation should increase in total cumulative conversion from cycle to cycle. This can be clearly seen in Figure 2 where the total $\mathrm{CaO}$ conversion to $\mathrm{CaCl}_{2}$ increases from approximately 2.1 to $10.0 \%$ over 10 cycles. This is further reinforced by the $\mathrm{CaO}-\mathrm{CaCl}_{2}$ phase diagram provided in Figure 3 , where high gas-to-solids ratios have been chosen to represent TGA conditions. Over a wide range of $\mathrm{HCl}$ and $\mathrm{CO}_{2}$ concentrations (balance $\mathrm{N}_{2}$ ) thermodynamic phase equilibrium analysis predicts that during carbonation at temperatures below approximately $770^{\circ} \mathrm{C}$, only solid phase $\mathrm{CaCl}_{2}$ should exist. Conversely, during calcination at temperatures above $770^{\circ} \mathrm{C}$ only a phase change from solid to liquid $\mathrm{CaCl}_{2}$ is predicted and, assuming the rate of evaporation is negligible over such short calcination periods, no loss in $\mathrm{CaCl}_{2}$ product can be expected. Figure 3 also indicates that under typical carbonation conditions the formation of $\mathrm{CaCl}_{2}$ is thermodynamically favoured over the formation of $\mathrm{CaCO}_{3}$. Therefore, lower carbonation conversions could be expected if carbonation time periods where increased. After several cycles the impact of the $\mathrm{CaCl}_{2}$ product layer becomes less prominent since thermal sintering of the sorbent during calcination becomes the dominant $\mathrm{CO}_{2}$ diffusional resistance (Lysikov, Salanov, \& Okunev, 2007). It should be noted that the phase equilibrium predictions in Figure 3 are unaffected by $\mathrm{CO}_{2}$ concentration ranging from 0 to $80 \mathrm{~mol} \%$, which covers all typical $\mathrm{CO}_{2}$ concentrations in both the carbonation and calcination regimes.

Interestingly, these results are somewhat different from those found by Wang et al. (2014), where it was reported that the carbonation conversions over the first 10 cycles were higher when $\mathrm{HCl}$ was present during carbonation. This phenomenon was attributed to a two-step mechanism where the surface of the calcined sorbent is initially converted to $\mathrm{CaCO}_{3}$, then subsequently reacted with $\mathrm{HCl}$ to form $\mathrm{CaCl}_{2}$ (Equation 4). During this process, $\mathrm{H}_{2} \mathrm{O}$ and $\mathrm{CO}_{2}$ release from the product layer could create additional porosity, lowering the $\mathrm{CO}_{2}$ diffusional resistance to the unreacted $\mathrm{CaO}$ core. Alternatively, Partanen et al. (2003) and Freidina \& Fray (2000) considered the $\mathrm{CaCl}_{2}-\mathrm{CaCO}_{3}$ product layer possibly forming a molten phase during carbonation at temperatures around $700^{\circ} \mathrm{C}$. This could reduce the diffusion limitations and explain the increased carbonation conversions in comparison to what is seen in Figure 2, where carbonation takes place at $650^{\circ} \mathrm{C}$. To investigate this phenomenon further a more detailed look at each carbonation cycle is required.

Presented in Figure 4 is a comparison of the carbonation conversion versus time data for the $3^{\text {rd }}$ and $9^{\text {th }}$ cycle with and without the presence of $\mathrm{HCl}$. It can be observed that although the total conversion over entire carbonation period is higher without the presence of $\mathrm{HCl}$, the initial rate of reaction in the kinetically controlled regime is greater when $\mathrm{HCl}$ is present. This result would suggest that chlorination of both $\mathrm{CaO}$ and $\mathrm{CaCO}_{3}$ is kinetically favoured over carbonation, but the release of $\mathrm{H}_{2} \mathrm{O}$ during the chlorination of $\mathrm{CaO}$ to $\mathrm{CaCl}_{2}$ increases the available surface area for carbonation through the 
creation of additional porosity as suggested by Wang et al. (2014). Figure 4 also clearly shows that the fast kinetically controlled regime period is reduced when $\mathrm{HCl}$ is present indicating that the formation of $\mathrm{CaCl}_{2}$ eventually has a negative effect on $\mathrm{CO}_{2}$ capture. This is mostly likely caused when a significant quantity of the active portion of the particle surface becomes covered in a layer of $\mathrm{CaCl}_{2}$, increasing the diffusional resistance. It is interesting to note that the initial rate of reaction remains constant from the $3^{\text {rd }}$ to the $9^{\text {th }}$ cycles when $\mathrm{HCl}$ is present, whereas there is a significant drop over repeated cycles in the absence of $\mathrm{HCl}$. As shown by Wang et al. (2014), the residual $\mathrm{CO}_{2}$ carrying capacity should eventually be reduced to near zero over an increased number of carbonation / calcination cycles, since more and more sorbent would be irreversibly converted to $\mathrm{CaCl}_{2}$ under these particular carbonation / calcination conditions.

An alternate theory that may help explain the reduced difference between carbonation conversions over repeated cycles with and without the presence of $\mathrm{HCl}$ is related to solid state diffusion where $\mathrm{Cl}$ migration may occur. The solid state diffusion of $\mathrm{CaCl}_{2}$ is enhanced at the higher calcination temperature when the $\mathrm{CaCl}_{2}$ is in the liquid state with the consequence that it migrates into the interior of the particle to some extent. This migration tends to occur at grain boundaries where solid state diffusion rates can be expected to be highest due to local lattice dislocations. Migration of the $\mathrm{Cl}$ into the interior of the particle during calcination results in a portion of the surface sites that had previously been $\mathrm{CaCl}_{2}$ forming $\mathrm{CaO}$, which is subsequently available for reaction with either additional $\mathrm{HCl}$ or with $\mathrm{CO}_{2}$. Due to this effect, the pore blockage that occurs is temporary and does not result in a large degradation in carbonation conversion over a large number of cycles. Thus, after 10 calcination / carbonation cycles, the carbonation conversion both with and without the presence of $\mathrm{HCl}$ tend towards the same value (Figure 2). This occurs despite the fact that the sum of the molar volumes of $\mathrm{CaCO}_{3}$ and $\mathrm{CaCl}_{2}$ in the particles that had been exposed to $\mathrm{HCl}$ is greater than the molar volume of $\mathrm{CaCO}_{3}$ in the particles that were not exposed to $\mathrm{HCl}$. Future testing with an extended number of calcination / carbonation cycles should be explored to further reinforce this theory. 


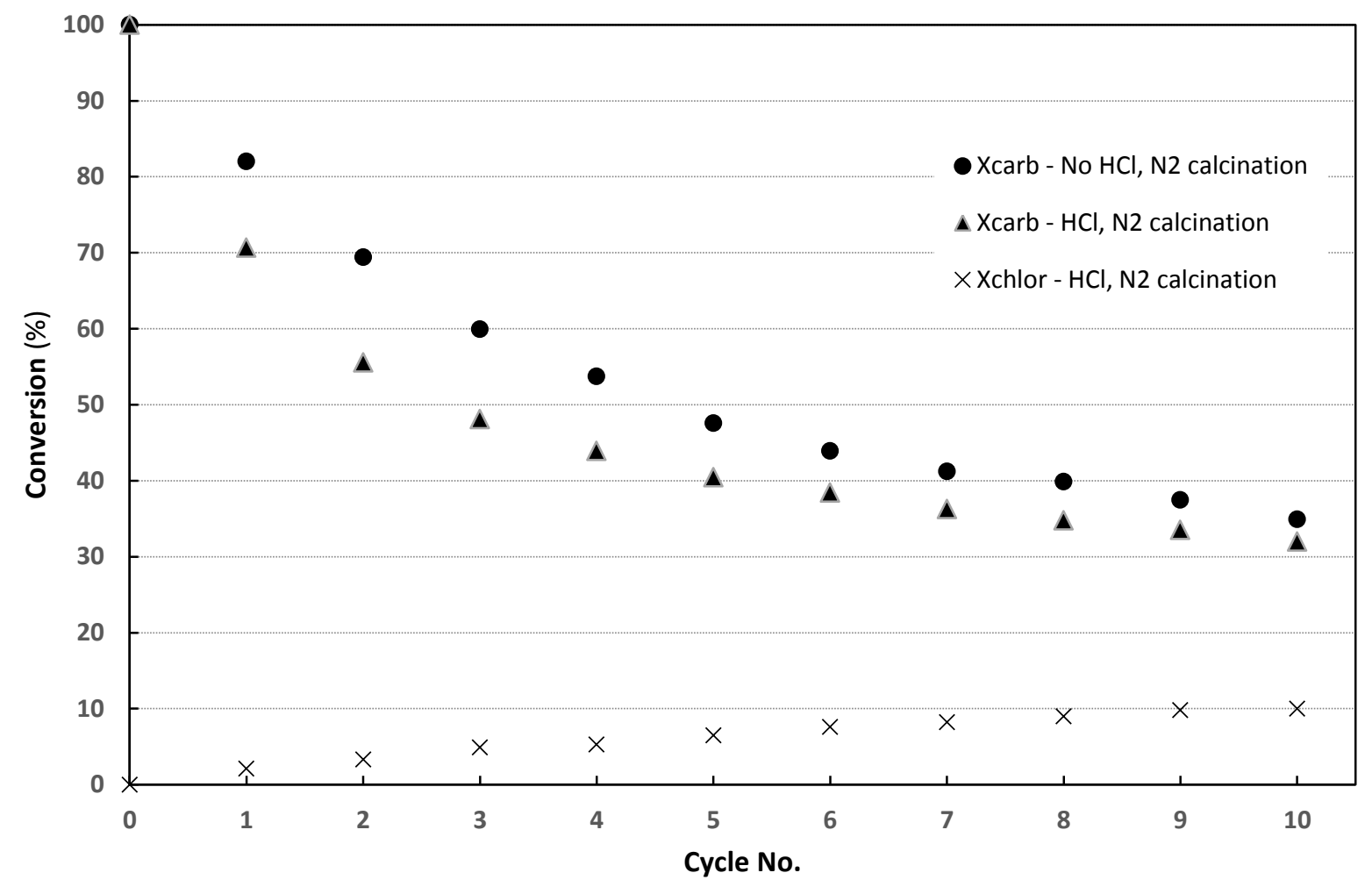

Figure 2: TGA carbonation and chlorination conversions over repeated calcination / carbonation cycles with and without the presence of $\mathrm{HCl}$ - Carbonation at $650^{\circ} \mathrm{C}\left(0\right.$ and $2000 \mathrm{ppm} \mathrm{HCl}, 15 \% \mathrm{CO}_{2}$, balance $\left.\mathrm{N}_{2}\right)$ and calcination at $870^{\circ} \mathrm{C}\left(100 \% \mathrm{~N}_{2}\right)$.

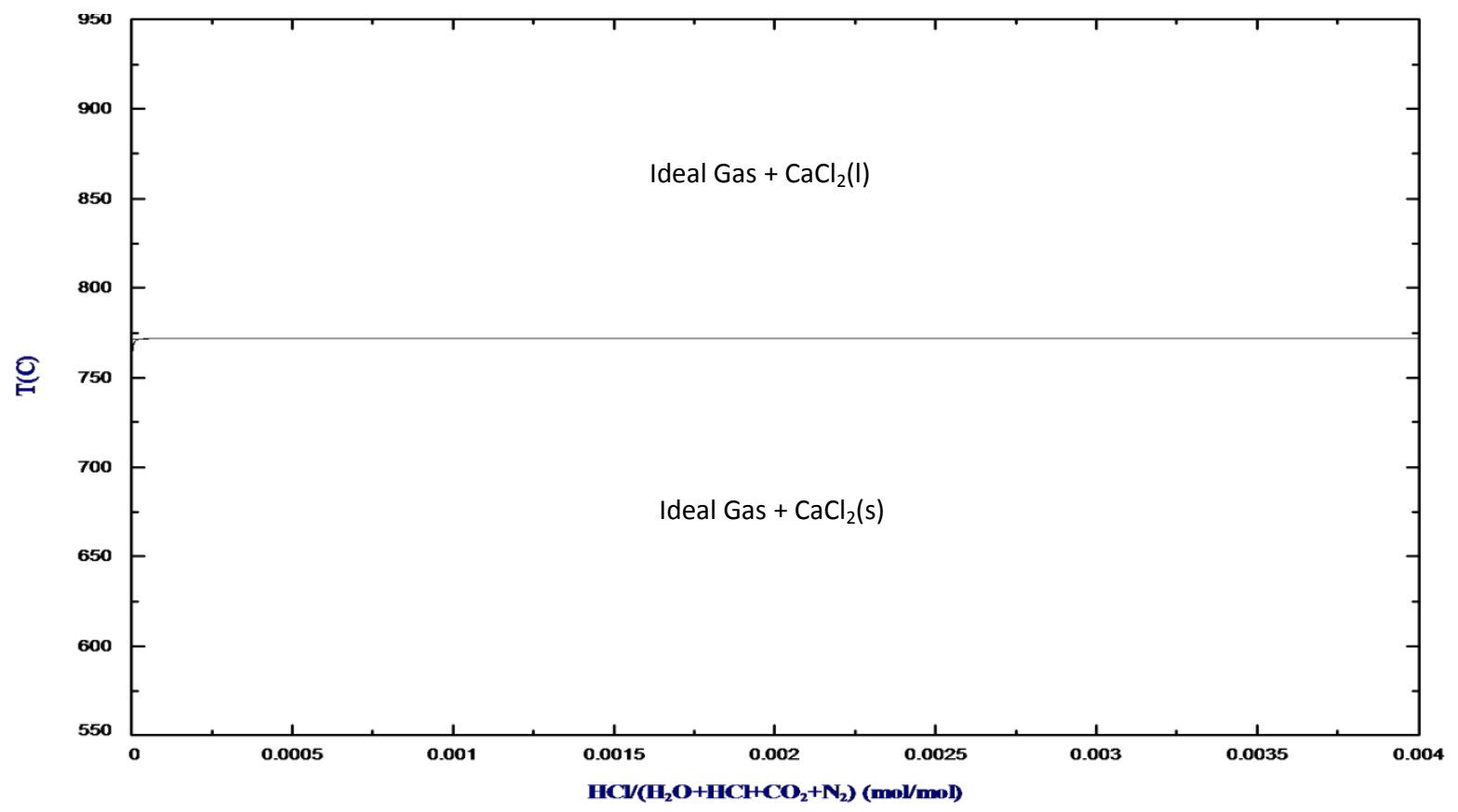

Figure 3: Thermodynamic phase diagram for the $\mathrm{CaO}-\mathrm{CaCl} 2$ system -1 atmosphere, $\mathrm{CO}_{2}=0$ to $80 \mathrm{~mol} \%$, $\mathrm{N}_{2}$ balance. 


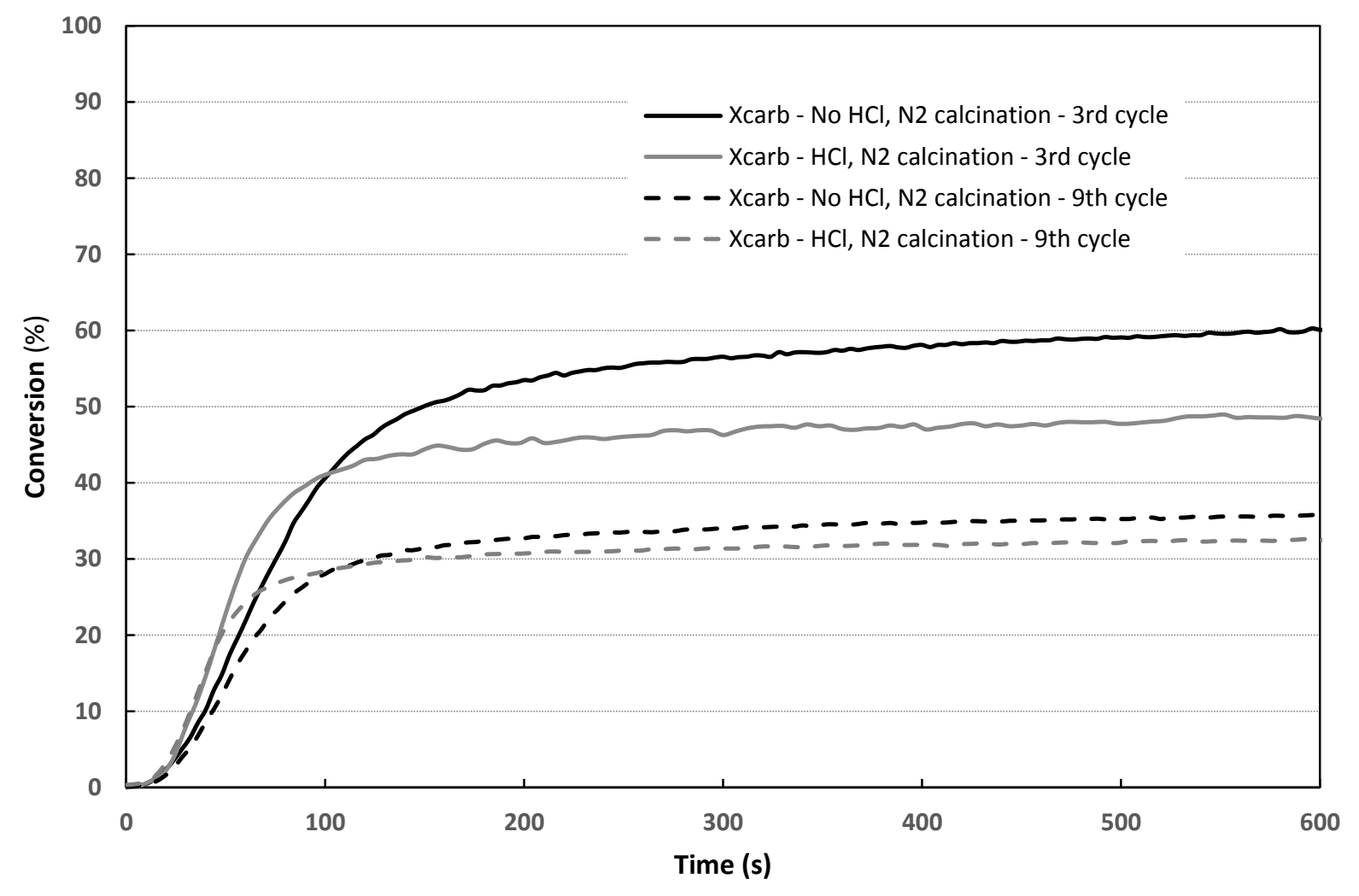

Figure 4: TGA carbonation conversion vs. time for $3^{\text {rd }}$ and $9^{\text {th }}$ carbonation cycle with and without the presence of $\mathrm{HCl}-$ Carbonation at $650^{\circ} \mathrm{C}\left(0\right.$ and $2000 \mathrm{ppm} \mathrm{HCl}, 15 \% \mathrm{CO}_{2}$, balance $\left.\mathrm{N}_{2}\right)$ and calcination at $870^{\circ} \mathrm{C}\left(100 \% \mathrm{~N}_{2}\right)$.

\subsection{Effect of $\mathrm{HCl}$ on $\mathrm{CO}_{2}$ capture with the presence of steam during calcination}

As shown above, the presence of $\mathrm{HCl}$ has a dramatic effect on the $\mathrm{CO}_{2}$ carrying capacity of $\mathrm{CaO}$ based sorbents over the first 10 cycles. These results however only consider a calcination environment containing pure $\mathrm{N}_{2}$, which would not be the case in a real system. The heat required to drive the endothermic calcination reaction would come from a carbonaceous source, meaning both $\mathrm{CO}_{2}$ and steam would be present during calcination and should be considered when examining the impact of $\mathrm{HCl}$ on the calcium looping process. Figure 5 presents thermodynamic phase equilibrium analysis predictions covering a wide range of $\mathrm{HCl}$ concentrations for both (a) $15 \mathrm{~mol} \% \mathrm{H}_{2} \mathrm{O}$ and (b) $30 \mathrm{~mol}^{2} \mathrm{H}_{2} \mathrm{O}$ with 60 mol\% $\mathrm{CO}_{2}$ and balance $\mathrm{N}_{2}$. These two steam concentrations represent both a dry and wet flue gas recycle common during oxy-fuel calcination operation. In comparison to calcination under pure $\mathrm{N}_{2}$, several key differences exist when steam is present. The first is that the transition from solid phase to liquid phase $\mathrm{CaCl}_{2}$ drops from approximately $770^{\circ} \mathrm{C}$ to $750^{\circ} \mathrm{C}$, which could have implications on the process if higher carbonation temperatures were employed. The second major difference, which can be considered the most significant, is that for $\mathrm{HCl}$ concentrations below $2000 \mathrm{ppm}$, no $\mathrm{CaCl}_{2}$ phases are predicted to exist above approximately $830^{\circ} \mathrm{C}$. When the $\mathrm{H}_{2} \mathrm{O}$ concentration is increased to $30 \mathrm{~mol} \%$, all phases predictions shift to the right; thus, higher $\mathrm{HCl}$ concentrations ( $>3500 \mathrm{ppm}$ ) are required to allow for the formation of $\mathrm{CaCl}_{2}$. These results suggest that any $\mathrm{CaCl}_{2}$ formed during the carbonation period, given enough time, would dechlorinate to $\mathrm{CaO}$ at typical calcination temperatures when steam is present. 

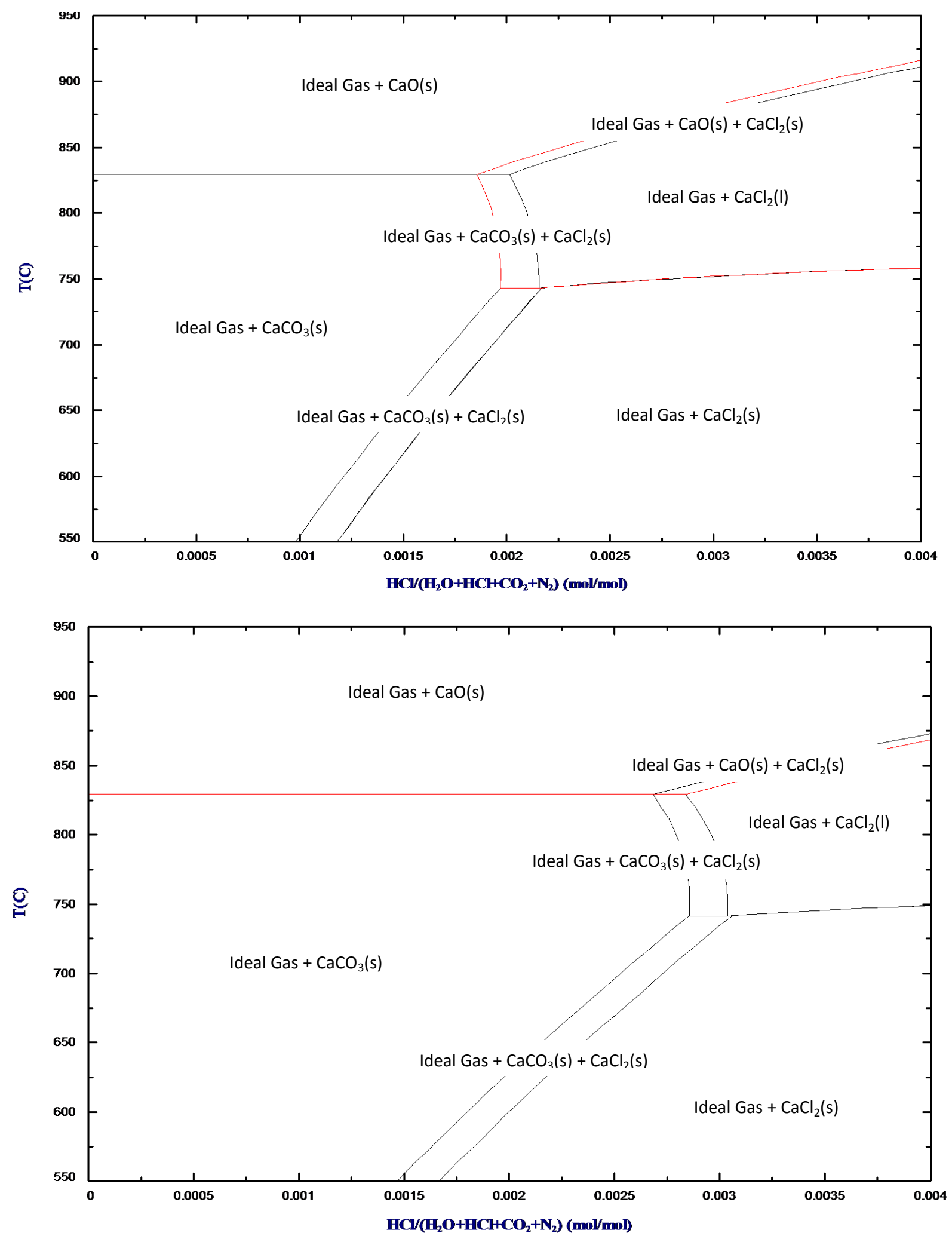

Figure 5: Thermodynamic phase diagram for the CaO-CaCl system - (a) Top - 1 atmosphere, $\mathrm{H}_{2} \mathrm{O}=15 \mathrm{~mol} \%, \mathrm{CO}_{2}=60 \mathrm{~mol} \%, \mathrm{~N}_{2}$ balance (b) Bottom - 1 atmosphere, $\mathrm{H}_{2} \mathrm{O}=30 \mathrm{~mol} \%, \mathrm{CO}_{2}=60 \mathrm{~mol} \%, \mathrm{~N}_{2}$ balance. 
A series of TGA tests were conducted to examine the effect of the presence of steam during calcination on the cyclic $\mathrm{CO}_{2}$ carrying capacity of Cadomin limestone. Carbonation conversions over repeated cycles with and without $\mathrm{HCl}$ present during carbonation (with steam during calcination) are depicted in Figure 6. In contrast to the results shown in Figure 2, the presence of $\mathrm{HCl}$ not only did not show a negative effect on carbonation conversion, but it in fact showed a positive effect from the $4^{\text {th }}$ cycle onwards. The first point to consider when examining these results is the fact that no increase in mass was recorded after calcination from cycle to cycle. This supports the theory that any $\mathrm{CaCl}_{2}$ formed during carbonation with $\mathrm{HCl}$ present is converted back to $\mathrm{CaO}$ during calcination, as predicted by thermodynamic phase equilibrium analysis (Figure 5). Therefore, chlorination conversions could not be determined for TGA tests under these conditions. Further analysis into chlorination conversions and potential residual $\mathrm{CaCl}_{2}$ under these conditions will be discussed in the subsequent Section (3.4), where fixed bed testing was employed.

As expected, the carbonation conversions without the presence of $\mathrm{HCl}$ were lower than those where calcination was performed under a pure $\mathrm{N}_{2}$ gaseous environment (Figure 2), as $\mathrm{CO}_{2}$ is known to accelerate sintering of calcium based sorbents especially over the first few cycles (Barker, 1973) (Silaban \& Harrison, 1995). This would explain why after the first cycle, the presence of $\mathrm{HCl}$ only drops the carbonation conversion by approximately 2.5 percentage points. After the first cycle, carbonation conversions begin to be at par or higher in the presence of $\mathrm{HCl}$, which would suggest that dechlorination during calcination impacts the subsequent carbonation. One explanation for this phenomenon could be the difference in molar volumes between $\mathrm{CaCl}_{2}$ and $\mathrm{CaCO}_{3}$ which causes the formation of larger pores at the particle surface and decreases the $\mathrm{CO}_{2}$ diffusional resistance during carbonation; a similar phenomenon observed during $\mathrm{CaO}$ hydration to $\mathrm{Ca}(\mathrm{OH})_{2}$ (Blamey, Lu, Fennell, \& Anthony, 2011). Presented in Figure 7 is a comparison of the carbonation conversion versus time data for the $6^{\text {th }}$ cycle with and without the presence of $\mathrm{HCl}$ and calcination under $15 \mathrm{~mol} \%$ steam conditions. The $6^{\text {th }}$ cycle was selected as this is the point where the carbonation conversion with and without $\mathrm{HCl}$ present start to significantly diverge. The initial fast kinetically controlled regime period is significantly reduced ( $\sim 0 \%)$ when $\mathrm{HCl}$ is present, which is further confirmation that the formation of $\mathrm{CaCl}_{2}$ limits the number of active $\mathrm{CaO}$ sites for reaction with $\mathrm{CO}_{2}$ on the particle surface. In contrast, the diffusion controlled regime period is not only extended, but there is also a substantial increase in the rate of reaction. This result would suggest that morphological changes are occurring, which are likely related to the decomposition of $\mathrm{CaCl}_{2}$ to $\mathrm{CaO}$ during calcination. It should be noted that the increased carbonation conversion via the addition of $\mathrm{HCl}$ during carbonation, provided steam is present during calcination, might not be realized during operation of commercial calcium looping system depending on the type fluidized bed used for carbonation. Circulating fluidized beds have average particle residence times on the order of minutes, which result in a lower carbonation conversion based on the results observed in Figure 7. In contrast, longer residence time bubbling fluidized beds could be employed to take advantage of the increased carbonation conversion due to the formation of $\mathrm{CaCl}_{2}$.

Identical carbonaceous fuel sources would most likely be used for the generation of the flue gas and for the suppling the required heat for calcination. Therefore, it was of interest to examine the effect of the presence of $\mathrm{HCl}$ during calcination on the $\mathrm{CO}_{2}$ carrying capacity of the sorbent over repeated cycles. Under a calcination temperature of $870^{\circ} \mathrm{C}$, the presence of $\mathrm{HCl}$ during calcination has little to no effect on carbonation conversion over 10 cycles (Figure 8). Based on the phase equilibrium predictions in Figure 5, the formation of $\mathrm{CaCl}_{2}$ is only possible at significantly higher $\mathrm{HCl}$ concentrations 
(>3500 ppm) or at lower $\mathrm{H}_{2} \mathrm{O}$ concentrations, both of which were not explored in this work. Since $\mathrm{HCl}$ concentrations above 2000 ppm and $\mathrm{H}_{2} \mathrm{O}$ concentrations below 15 mol\% are never expected under any oxy-fuel combustion operating scenario, no further attention was given to the impact of $\mathrm{HCl}$ during calcination.

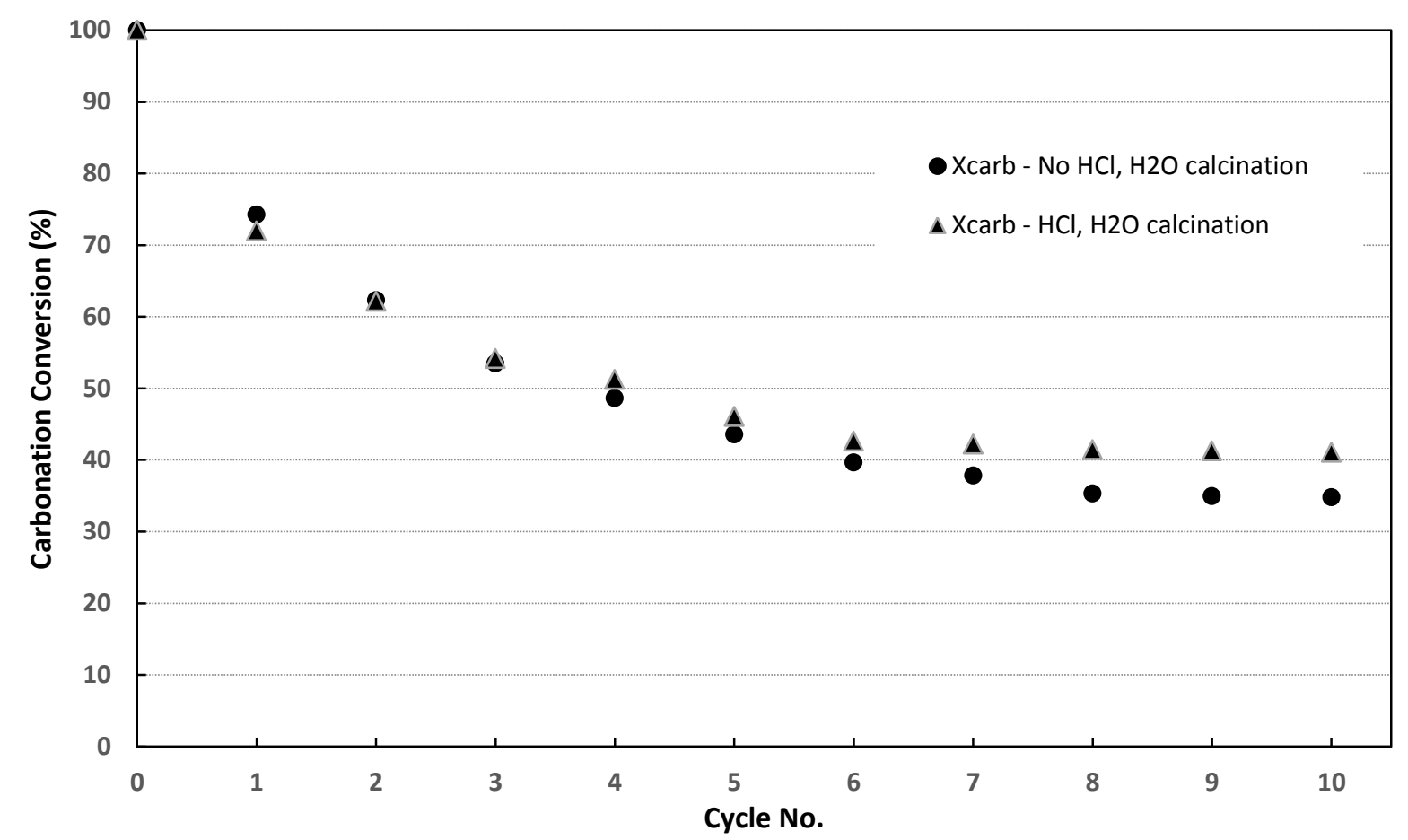

Figure 6: TGA carbonation conversions over repeated calcination / carbonation cycles with and without the presence of $\mathrm{HCl}$ Carbonation at $650^{\circ} \mathrm{C}\left(\mathrm{O}\right.$ and $2000 \mathrm{ppm} \mathrm{HCl}, 15 \% \mathrm{CO}_{2}$, balance $\left.\mathrm{N}_{2}\right)$ and calcination at $870^{\circ} \mathrm{C}\left(60 \% \mathrm{CO}_{2}, 15 \% \mathrm{H}_{2} \mathrm{O}\right.$, balance $\left.\mathrm{N}_{2}\right)$. 


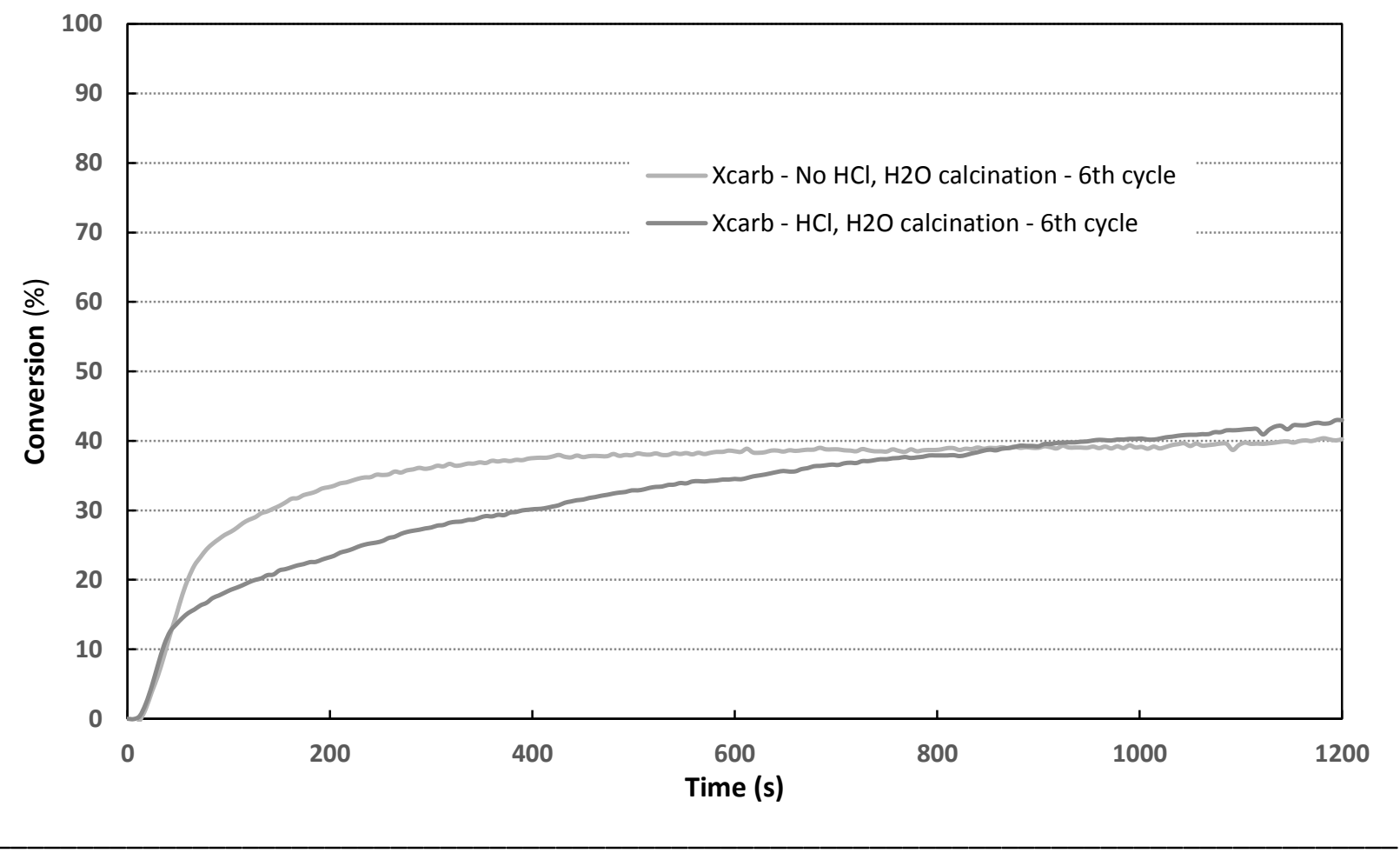

Figure 7: TGA carbonation conversion vs. time for $6^{\text {th }}$ carbonation cycle with and without the presence of $\mathrm{HCl}-\mathrm{Carbonation}$ at $650^{\circ} \mathrm{C}\left(\mathrm{O}\right.$ and $2000 \mathrm{ppm} \mathrm{HCl}, 15 \% \mathrm{CO}_{2}$, balance $\left.\mathrm{N}_{2}\right)$ and calcination at $870^{\circ} \mathrm{C}\left(60 \% \mathrm{CO}_{2}, 15 \% \mathrm{H}_{2} \mathrm{O}\right.$, balance $\left.\mathrm{N}_{2}\right)$. 


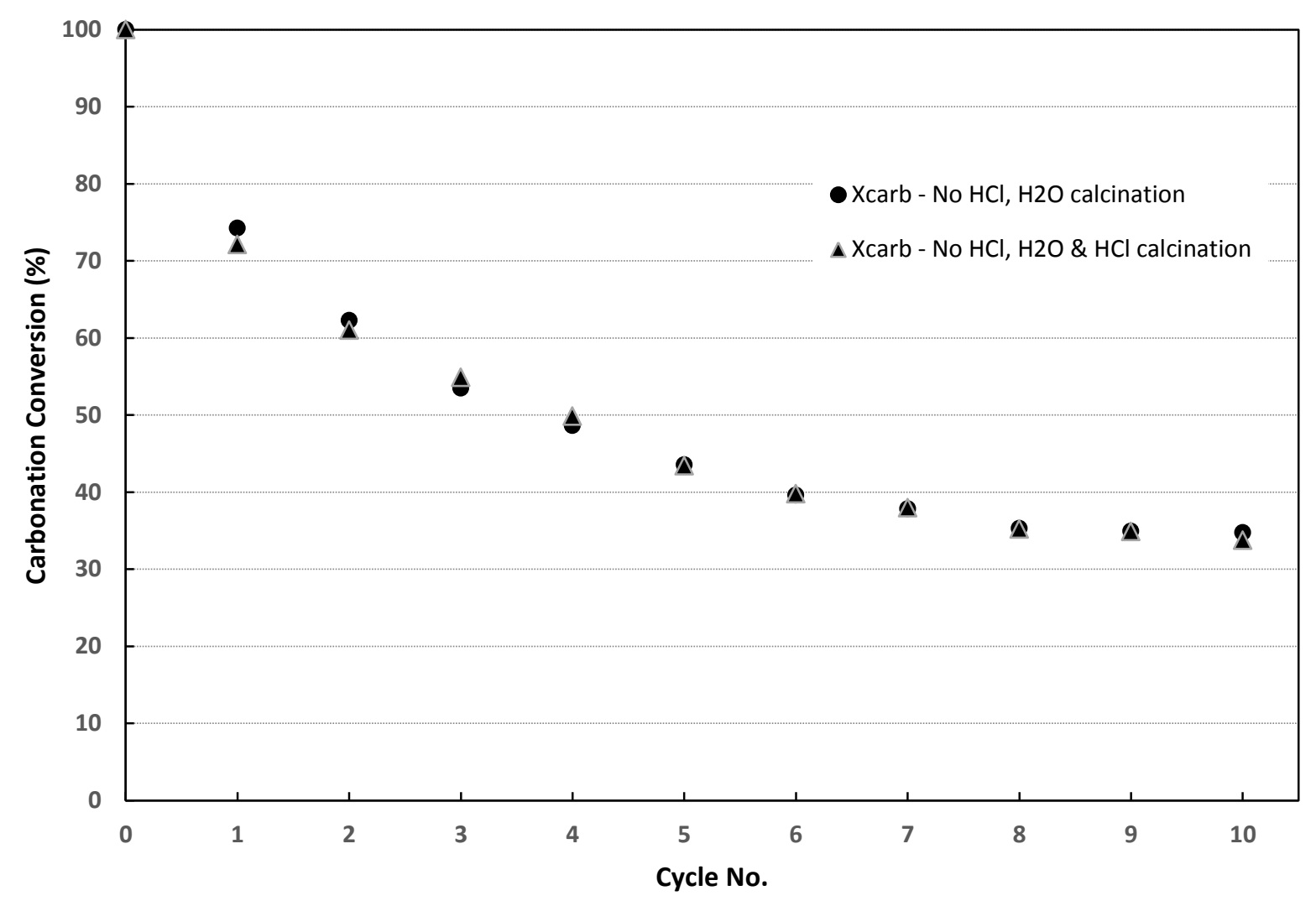

Figure 8: TGA carbonation conversions over repeated calcination / carbonation cycles with and without the presence of $\mathrm{HCl}$ during calcination - Carbonation at $650^{\circ} \mathrm{C}\left(15 \% \mathrm{CO}_{2}\right.$, balance $\left.\mathrm{N}_{2}\right)$ and calcination at $870^{\circ} \mathrm{C}(0$ and $2000 \mathrm{ppm} \mathrm{HCl}, 60 \% \mathrm{CO}, 15 \%$ $\mathrm{H}_{2} \mathrm{O}$, balance $\mathrm{N}_{2}$ ).

\subsection{Effect of $\mathrm{HCl}$ on $\mathrm{CO}_{2}$ capture with the presence of steam during carbonation}

Steam addition during carbonation has been shown to improve sorbent performance, with the effect becoming more pronounced after multiple cycles (Symonds, Lu, Macchi, Hughes, \& Anthony, 2009) (Manovic \& Anthony, 2010) (Symonds, Lu, Hughes, Anthony, \& Macchi, 2009). This phenomenon has been interpreted in several ways including: catalytic improvement of the capture process through hydration of $\mathrm{CaO}$ at the surface of the sorbent or enhancement of $\mathrm{CO}_{2}$ mobility due to reduction in diffusion resistance (Champagne, Lu, Macchi, Symonds, \& Anthony, 2012). Numerous more recent studies on the addition of steam during carbonation have also confirmed the previous results, while indicating that steam has little to no influence on the initial reaction rate, but enhances the diffusion controlled regime of carbonation (Dou, Song, Liu, \& Feng, 2010) (Arias, Abanades, Grasa, Manovic, \& Anthony, 2012). Figure 9 depicts the carbonation conversions over 10 cycles with ( $15 \mathrm{~mol} \% \mathrm{steam}$ ) and without steam present during carbonation. As expected, the conversions were substantially higher when steam was present, with the largest enhancements observed after the $5^{\text {th }}$ cycle and onwards ( 10 percentage points difference after the $10^{\text {th }}$ cycle). Although not shown here, the initial fast, kinetically controlled regime was unchanged when steam was present.

Also shown in Figure 9 are the carbonation conversions over repeated cycles for a case where both steam and $\mathrm{HCl}$ were present during carbonation. Over all 10 cycles the measured conversions were higher than (1) without $\mathrm{HCl}$ and (2) just steam present. This result is in alignment with what was 
observed in Figure 6, where it was proposed that the increase in carbonation conversion was caused by the formation of larger pores at the particle surface during the decomposition of $\mathrm{CaCl}_{2}$ to $\mathrm{CaO}$ during calcination. It should be noted that when no steam was present during carbonation the effect of $\mathrm{HCl}$ was larger than when steam was present. After 10 cycles, the presence of $\mathrm{HCl}$ showed a 6.3 and 2.7 percentage point increase in carbonation conversion with and without steam present, respectively. Plausible explanations for this decrease in relative improvement include: (1) the steam enhancement during the diffusion controlled regime significantly outweighs any improvement to the particle morphology during calcination and (2) $\mathrm{CaCl}_{2}$ conversion is suppressed via the presence of steam during carbonation.

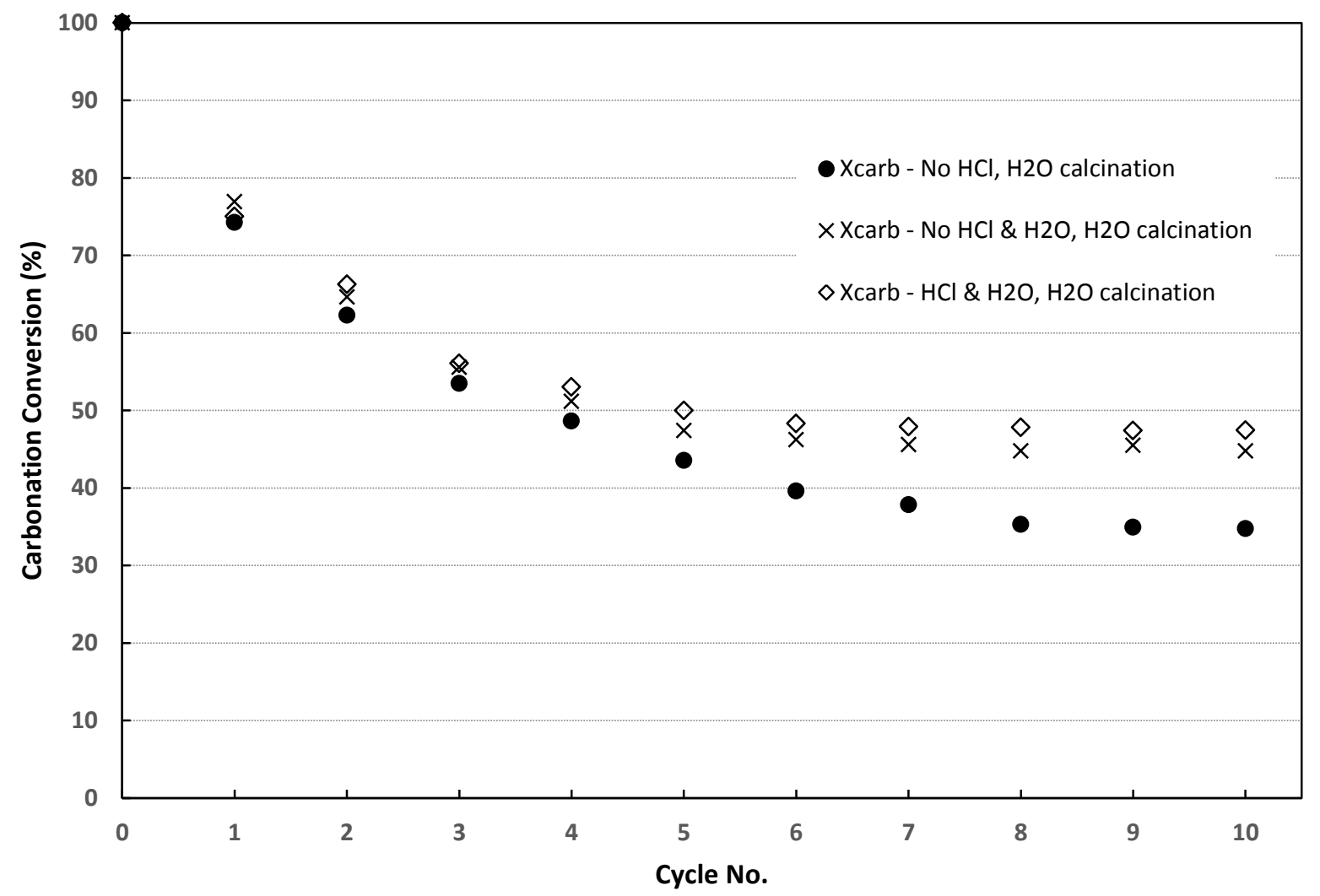

Figure 9: TGA carbonation conversions over repeated calcination / carbonation cycles with and without the presence of $\mathrm{HCl}$ and $\mathrm{H}_{2} \mathrm{O}$ during carbonation - Carbonation at $650^{\circ} \mathrm{C}\left(\mathrm{O}\right.$ and $2000 \mathrm{ppm} \mathrm{HCl}, \mathrm{O}$ and $15 \% \mathrm{H}_{2} \mathrm{O}, 15 \% \mathrm{CO}_{2}$, balance $\mathrm{N}_{2}$ ) and calcination at $870^{\circ} \mathrm{C}\left(60 \% \mathrm{CO}_{2}, 15 \% \mathrm{H}_{2} \mathrm{O}\right.$, balance $\left.\mathrm{N}_{2}\right)$. 

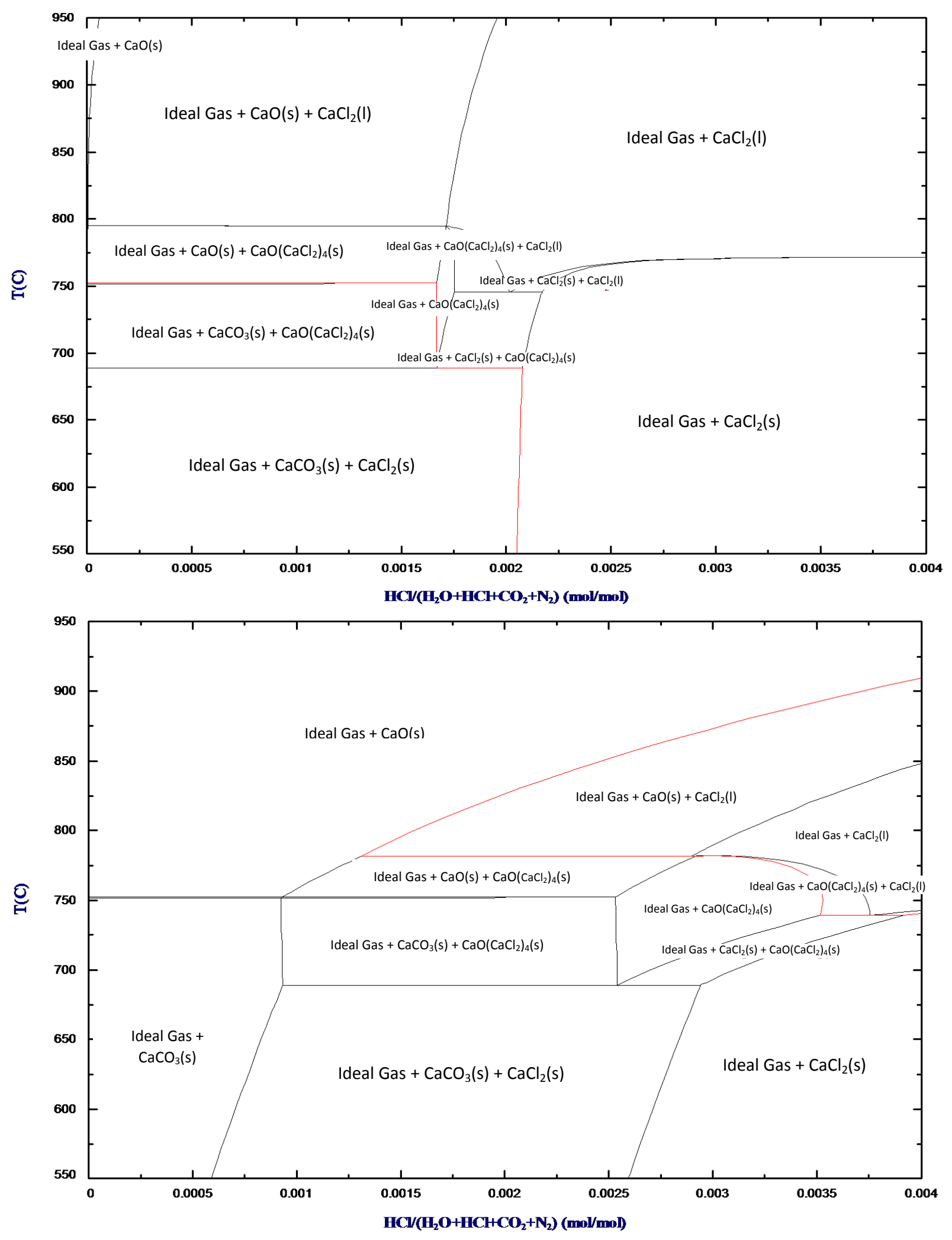

Figure 10: Thermodynamic phase diagram for the $\mathrm{CaO}-\mathrm{CaCl}_{2}$ system - (a) Top - 1 atmosphere, $\mathrm{H}_{2} \mathrm{O}=0 \mathrm{~mol} \%, \mathrm{CO}_{2}=15 \mathrm{~mol} \%, \mathrm{~N}_{2}$ balance (b) Bottom - 1 atmosphere, $\mathrm{H}_{2} \mathrm{O}=15 \mathrm{~mol} \%, \mathrm{CO}_{2}=15 \mathrm{~mol} \%, \mathrm{~N}_{2}$ balance. 
Figure 10 presents thermodynamic phase equilibrium analysis predictions under typical carbonation conditions, covering a wide range of $\mathrm{HCl}$ concentrations for both (a) 0 mol\% $\mathrm{H}_{2} \mathrm{O}$ and (b) 15 mol\% $\mathrm{H}_{2} \mathrm{O}$ with 15 mol\% $\mathrm{CO}_{2}$ and balance $\mathrm{N}_{2}$. From this figure, several key observations can be made. The first is that at carbonation temperatures below approximately $690^{\circ} \mathrm{C}$ both $\mathrm{CaCO}_{3}$ and $\mathrm{CaCl}_{2}$ should be formed, but the creation of $\mathrm{CaO}\left(\mathrm{CaCl}_{2}\right)_{4}$ is possible at temperatures above $690^{\circ} \mathrm{C}$ up to melting point of $\mathrm{CaCl}_{2}$. Although temperatures above $690^{\circ} \mathrm{C}$ were not explored in this work, it is believed that such higher carbonation temperatures should be avoided when $\mathrm{HCl}$ is present since the formation of $\mathrm{CaO}\left(\mathrm{CaCl}_{2}\right)_{4}$ would most likely limit the availability of $\mathrm{CaO}$ for $\mathrm{CO}_{2}$ capture and could cause significant pore blockage. The second key observation is that the presence of steam significantly suppresses the formation of $\mathrm{CaCl}_{2}$. When comparing Figure 10a to Figure $10 \mathrm{~b}$ there is clear shift in the phase envelopes towards the right, and under low enough $\mathrm{HCl}$ concentrations $(<600 \mathrm{ppm})$, it is possible to avoid any formation of $\mathrm{CaCl}_{2}$. Increasing the steam concentration further would increase the minimum $\mathrm{HCl}$ concentration required for chlorination, although this might not be practical since (1) the presence of $\mathrm{HCl}$ has been shown to improve carbonation conversion with steam present during calcination and (2) adding additional steam to the carbonator would most likely reduce the overall process efficiency of the calcium looping process. Nevertheless, minimizing or eliminating $\mathrm{HCl}$ capture in the carbonator could be advantageous in cases where $\mathrm{HCl}$ removal from the concentrated $\mathrm{CO}_{2}$ calciner flue gas is difficult or not cost-effective. This issue is especially important since the $\mathrm{HCl}$ concentrations in the calciner flue gas would be significantly higher now due to dechlorination, which could lead to corrosion and equipment failure (Hjornhede, Sotkovszki, \& Nylund, 2006). In some circumstances, $\mathrm{HCl}$ could become the dominant species controlling acid dew point similar to $\mathrm{SO}_{2} / \mathrm{SO}_{3}$ in most typical combustion systems. For the $\mathrm{HCl}$ concentration utilized in this work $(2000 \mathrm{ppm})$, the formation of $\mathrm{CaCl}_{2}$ is still expected even with the presence of $15 \mathrm{~mol} \% \mathrm{H}_{2} \mathrm{O}$, as can be seen in Figure 10b. However, the rate of chlorination should be reduced since the difference between the $\mathrm{HCl}$ concentration in the bulk gas and the equilibrium has been decreased. Since all carbonation cycles shown in Figure 9 were performed at $650^{\circ} \mathrm{C}$ with 15 mol\% $\mathrm{CO}_{2}$ in the reaction gas, it is expected that there would be a reduction in $\mathrm{CaCl}_{2}$ formation in comparison to without the presence of steam. The lower level of chlorination could explain why a smaller relative improvement in carbonation conversion was measured when steam was present.

\subsection{Fixed bed testing and microstructure analysis}

A series of fixed bed tests were performed to further explore the effect of $\mathrm{HCl}$ on $\mathrm{CO}_{2}$ capture and to allow for microstructure analysis via SEM/EDX and BET/BJH. Figure 11 shows the carbonation conversions over 6 cycles both with and without $\mathrm{HCl}$ and steam present during carbonation at $650^{\circ} \mathrm{C}$ with $15 \mathrm{~mol} \% \mathrm{CO}_{2}$. In each case, calcination was performed at $870^{\circ} \mathrm{C}$ under a $60 \mathrm{~mol} \% \mathrm{CO}_{2}, 15 \mathrm{~mol} \% \mathrm{H}_{2} \mathrm{O}$ with balance $\mathrm{N}_{2}$ environment. Like the TGA tests discussed earlier (Figure 6 and Figure 9), the presence of $\mathrm{HCl}$ improves the carbonation conversion over repeated cycles. The average increase in carbonation conversion over 6 cycles without steam present was only $\sim 1.2$ percentage points, which would indicate that the effect of $\mathrm{HCl}$ is limited in comparison to the TGA tests. A plausible explanation for the difference between TGA and fixed bed reactor tests could be related to the level of chlorination of the sorbent sample. Based on the results presented in Figure 2, where the chlorination conversion could be measured, a single cycle chlorination conversion is in the 1 to $2 \%$ range under the conditions utilized in this work. The maximum chlorination conversion measured for any fixed bed reactor test was approximately $0.32 \%$ for a single cycle. During calcination, this would limit the formation of larger pores at the particle surface, decreasing the enhancement to $\mathrm{CO}_{2}$ diffusion during carbonation in comparison to cases where a higher level of $\mathrm{CaCl}_{2}$ formation had occurred. A similar result can also be seen in Figure 
11 for the case where steam is present during carbonation. The addition of steam improves the carbonation conversion, but the presence of $\mathrm{HCl}$ only results in a 0.33 percentage point increase in the average carbonation conversion over 6 cycles. It was expected that steam suppression of the chlorination reaction would have caused the limited improvement in carbonation conversion, but as was the case for all fixed bed reactor tests, the chlorination conversion and $\mathrm{HCl}$ capture values were nearly identical. For each carbonation cycle the chlorination conversions ranged between 0.30 and $0.32 \%$ and the $\mathrm{HCl}$ capture was greater than $99 \%$. The high capture efficiencies were due the large excess of sorbent in relation to the total flowrate of $\mathrm{HCl}$ sent to the fixed bed reactor. Under these conditions, it is possible that the steam enhancement during the diffusion controlled regime significantly outweighs any improvement to the particle morphology during calcination via decomposition of $\mathrm{CaCl}_{2}$ to $\mathrm{CaO}$. It should be noted that, regardless of carbonation condition during fixed bed reactor testing (both with and without $\mathrm{HCl}$ and steam), the initial carbonation conversions were significantly lower than during TGA testing and essentially remained constant over all 6 cycles. This phenomenon is in alignment with previous studies which showed that, under more severe calcination conditions (higher local $\mathrm{CO}_{2}$ concentrations and higher heating rates) seen during fixed bed and pilot-plant testing, carbonation conversions do not decay gradually over several cycles (Grasa \& Abanades, 2006), but instead drop immediately $\left(1^{\text {st }}\right.$ cycle) and remain relatively constant over repeated cycles (Champagne, Lu, Symonds, Macchi, \& Anthony, 2016) (Symonds, Champagne, Firas, \& Lu, 2016).

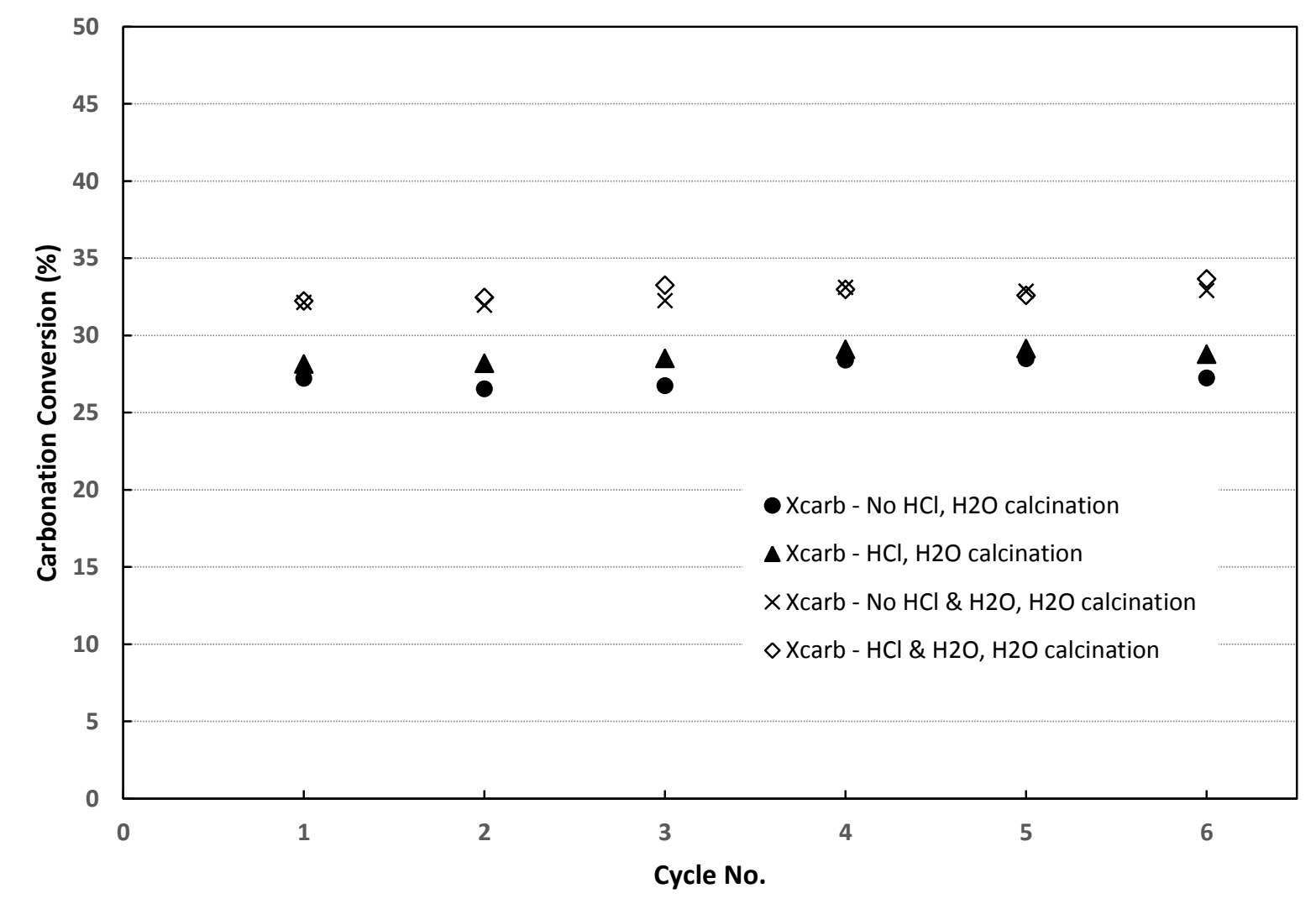

Figure 11: Fixed bed reactor carbonation conversions over repeated calcination / carbonation cycles with and without the presence of $\mathrm{HCl}$ and $\mathrm{H}_{2} \mathrm{O}$ during carbonation - Carbonation at $650^{\circ} \mathrm{C}\left(\mathrm{O}\right.$ and $2000 \mathrm{ppm} \mathrm{HCl}, \mathrm{O}$ and $15 \% \mathrm{H}_{2} \mathrm{O}, 15 \% \mathrm{CO}_{2}$, balance $\mathrm{N}_{2}$ ) and calcination at $870^{\circ} \mathrm{C}\left(60 \% \mathrm{CO}_{2}, 15 \% \mathrm{H}_{2} \mathrm{O}\right.$, balance $\left.\mathrm{N}_{2}\right)$. 
Figure 12(a) and (b) present SEM images of the calcined sorbent after 6 carbonation / calcination cycles without and with the presence of $\mathrm{HCl}$ during carbonation, respectively. Without the presence of $\mathrm{HCl}$, it was observed that there are a lot of smooth, compact, and non-porous zones on the surface of the particle. In comparison, the particle surface with the presence of $\mathrm{HCl}$ showed larger cracks / voids and significantly more porosity on the particle grain surfaces. This result would suggest that the particles that are exposed to $\mathrm{HCl}$ during carbonation should have higher surface area and pore volumes, which has been correlated to higher carbonation conversions (Sun, Lim, \& Grace, 2008). To further investigate, particle surface area and pore volume measurements were made via BET and BJH analyses and are presented Table 4. Particles carbonated with $\mathrm{HCl}$ present showed higher surface area and pore volume after 6 carbonation / calcination cycles which support the results observed in Figure 12 and is in alignment with the hypothesis that the decomposition of $\mathrm{CaCl}_{2}$ to $\mathrm{CaO}$ during calcination improves the particle morphology in terms of $\mathrm{CO}_{2}$ capture potential. Only $\sim 11.6 \%$ and $\sim 28.4 \%$ increases in surface area and pore volume, respectively, were measured with the addition of $\mathrm{HCl}$ when steam was present. In contrast, the surface area and pore volume where roughly $39 \%$ higher (for both) in the absence of steam when $\mathrm{HCl}$ was added during carbonation. Interestingly, this observed increase in surface area and pore volume did not result in a significant increase in carbonation conversion (Figure 11). Similar to the results shown in Figure 7 , the increase in carbonation conversion when $\mathrm{HCl}$ is present is only expected to be substantial during the diffusion control regime. Therefore, it is likely that higher carbonation conversion would have been achieved with $\mathrm{HCl}$ present if the carbonation period was extended further into this regime. It is uncertain why the surface area and pore volume increase was lower during carbonation with steam, but could be related to the higher carbonation conversion observed during the diffusion controlled regime when steam is present (Champagne, Lu, Macchi, Symonds, \& Anthony, 2012). In any case, it can be concluded that, under more realistic operating conditions experienced during fixed bed reactor testing, the presence of $\mathrm{HCl}$ has little or no effect on the carbonation conversion over repeated cycles when the flue gas contains steam. This result is significant since (1) this would be the case in any commercial-scale calcium looping facility and (2) high $\mathrm{HCl}$ capture efficiencies can still be achieved, reducing up or down stream gas clean-up of the post-combustion flue gas.

Both TGA and thermodynamic phase diagram analyses showed that given enough time at appropriate calcination conditions (high temperature and steam present), any $\mathrm{CaCl}_{2}$ formed during the carbonation period should decompose. Therefore, it was of interest to determine if any residual $\mathrm{CaCl}_{2}$ remained after calcination for fixed bed reactor tests performed with the presence $\mathrm{HCl}$ during carbonation. Since it was anticipated that the majority of $\mathrm{CaCl}_{2}$ formed during the carbonation period would be on the surface of the particle under these conditions, EDX analysis was performed on the surface of several particles after the final calcination. In all cases, no $\mathrm{Cl}$ was detected on the surface of any particle. This confirms that (1) the concentration of steam (15 mol\%) is suitable for the full decomposition of $\mathrm{CaCl}_{2}$, which is in alignment with FactSage phase predictions, and (2) the decomposition of $\mathrm{CaCl}_{2}$ is fast enough to be completed within the $\mathrm{CaCO}_{3}$ calcination time frame. This is important since calcination times are significantly shorter ( 1-minute time scale) in circulating fluidized beds (CFB) systems utilized in commercial-scale operation. Any residual $\mathrm{CaCl}_{2}$ not decomposed during the calcination period could severely reduce the sorbent $\mathrm{CO}_{2}$ carrying capacity over repeated cycles as shown in this work and by Wang et al. (2014). 
Table 4: Surface area and pore volume of calcined sorbent particles after 6 fixed bed reactor cycles.

\begin{tabular}{|c|c|c|c|}
\hline Run No. & Carbonation Condition & BET Surface Area $\left(\mathrm{m}^{2} / \mathrm{g}\right)$ & BJH Pore Volume $\left(\mathrm{cm}^{3} / \mathrm{g}\right)$ \\
\hline 1 & No $\mathrm{HCl}$, no steam & 3.21 & 0.00447 \\
\hline 2 & $\mathrm{HCl}$, no steam & 4.47 & 0.00625 \\
\hline 3 & No $\mathrm{HCl}$, steam & 3.51 & 0.00504 \\
\hline 4 & $\mathrm{HCl}$, steam & 3.92 & 0.00647 \\
\hline
\end{tabular}



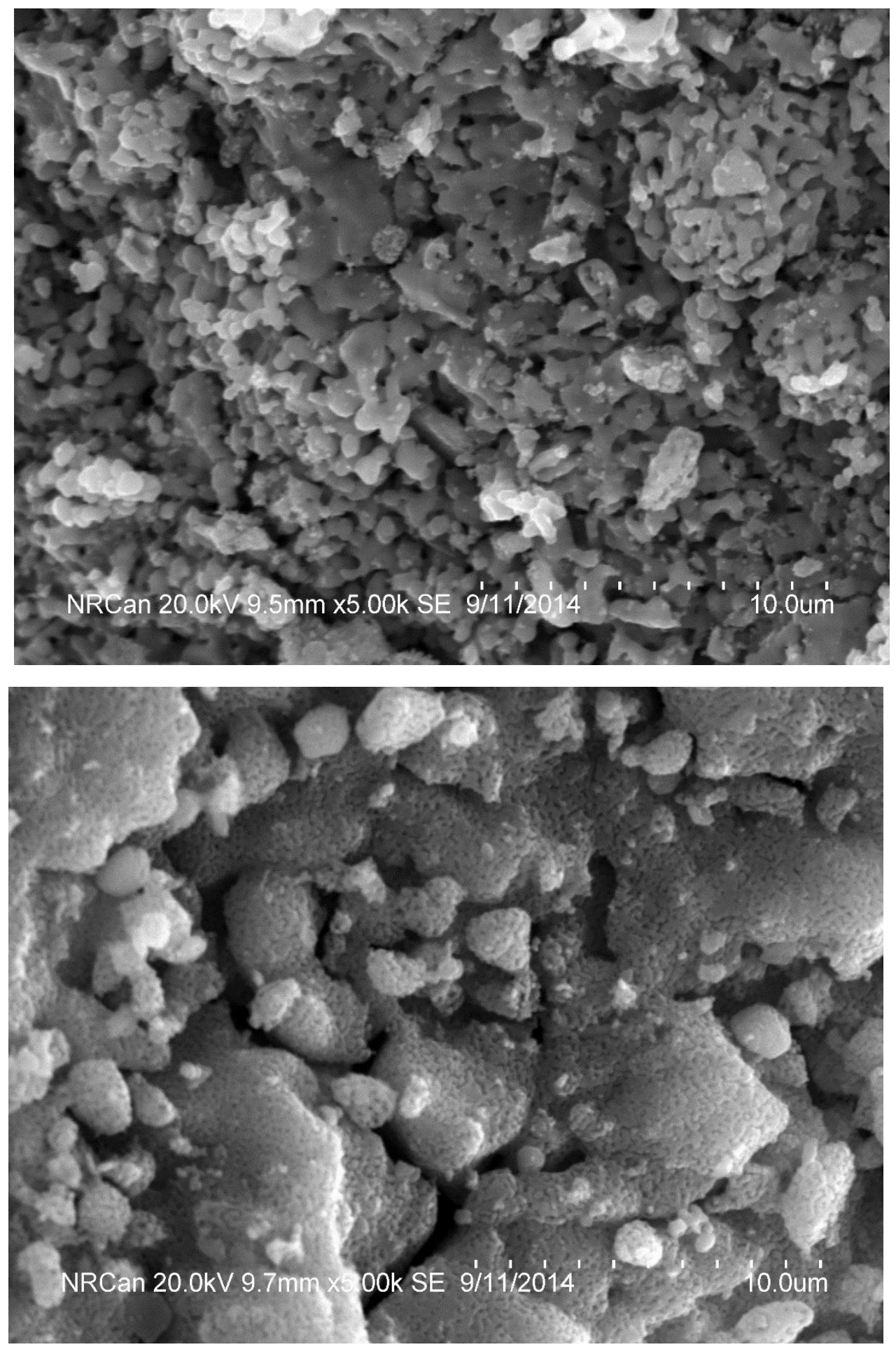

Figure 12: SEM images of calcined sorbent (Cadomin) particles after 6 fixed bed reactor cycles - (a) Top - carbonation at $650^{\circ} \mathrm{C}$ (0 ppm HCl, $\mathrm{O}$ and $15 \% \mathrm{H}_{2} \mathrm{O}, 15 \% \mathrm{CO}_{2}$, balance $\mathrm{N}_{2}$ ) (b) Bottom - carbonation at $650^{\circ} \mathrm{C}\left(2000 \mathrm{ppm} \mathrm{HCl}, 0\right.$ and $15 \% \mathrm{H}_{2} \mathrm{O}, 15 \% \mathrm{CO}_{2}$, balance $\left.\mathrm{N}_{2}\right)$ both calcinations at $870^{\circ} \mathrm{C}\left(60 \% \mathrm{CO}_{2}, 15 \% \mathrm{H}_{2} \mathrm{O}\right.$, balance $\left.\mathrm{N}_{2}\right)$. 


\section{Conclusions}

The effects of $\mathrm{HCl}$ injection during carbonation and calcination on the $\mathrm{CO}_{2}$ carrying capacity of Cadomin limestone $(250$ to $425 \mu \mathrm{m}$ ) have been studied via thermogravimetric analysis and fixed bed reactor testing. Preliminary testing under a pure $\mathrm{N}_{2}$ calcination environment at $870^{\circ} \mathrm{C}$ showed that the presence of $\mathrm{HCl}$ during carbonation led to the irreversible formation of $\mathrm{CaCl}_{2}$, which was supported by phase equilibria analysis. This resulted in lower carbonation conversions over repeated cycles due to a significant quantity of the active portion of the particle surface becoming covered in a layer of $\mathrm{CaCl}_{2}$, increasing the diffusional resistance. After ten calcination / carbonation cycles the carbonation conversion dropped by $\sim 3$ percentage points in comparison to without $\mathrm{HCl}$ present and is expected to continue to decrease as the number of cycles is increased.

The addition of steam during calcination provided very different results than those under pure $\mathrm{N}_{2}$. The carbonation conversions over repeated cycles were higher with the presence of $\mathrm{HCl}$, which was attributed to the decomposition of $\mathrm{CaCl}_{2}$ to $\mathrm{CaO}$ during calcination, supported by phase equilibria analyses. It was hypothesized that the difference in molar volumes between $\mathrm{CaCl}_{2}$ and $\mathrm{CaCO}_{3}$ causes the formation of larger pores at the particle surface during calcination, decreasing the $\mathrm{CO}_{2}$ diffusional resistance during carbonation. As expected, the addition of steam during carbonation increased the carbonation conversion over repeated cycles. The improvement to carbonation conversion caused by $\mathrm{HCl}$ addition was limited when steam was present as sorbent chlorination was suppressed.

Fixed bed test results confirmed that full decomposition of $\mathrm{CaCl}_{2}$ to $\mathrm{CaO}$ could be expected under typically oxy-fuel calcination conditions. Additionally, the presence of $\mathrm{HCl}$ during carbonation increased both the surface area and pore volume of the sorbent after 6 carbonation / calcination cycles, which further reinforces the hypothesis that dechlorination during calcination results in a particle structure that increases carbonation reactivity. Fixed bed testing also showed that greater than $99 \% \mathrm{HCl}$ capture could be achieved without adversely affecting sorbent $\mathrm{CO}_{2}$ capture performance when steam is present during both carbonation and calcination. Unfortunately, due to $\mathrm{CaCl}_{2}$ decomposition during calcination, $\mathrm{HCl}$ concentrations in the concentrated $\mathrm{CO}_{2}$ product stream could be relatively high. This could lead to potential corrosion and equipment failure issues if not appropriately addressed.

$$
\begin{aligned}
& \text { Nomenclature } \\
& C_{\mathrm{CO}_{2}} \text { outlet concentration of } \mathrm{CO}_{2} \text {, vol\% } \\
& C_{\mathrm{HCl}} \text { outlet concentration of } \mathrm{HCl} \text {, vol\% } \\
& F_{\mathrm{CO}_{2}, 0} \text { inlet flowrate of } \mathrm{CO}_{2}, \mathrm{~m}^{3} / \mathrm{min} \\
& F_{\mathrm{HCl}, 0} \text { inlet flowrate of } \mathrm{HCl}, \mathrm{m}^{3} / \mathrm{min} \\
& F_{\mathrm{Outlet}} \text { total outlet flowrate, } \mathrm{m}^{3} / \mathrm{min} \\
& m_{0} \quad \text { initial sample mass, } \mathrm{g} \\
& m_{\text {calc }} \text { mass of sample after calcination, } \mathrm{g} \\
& m_{\mathrm{carb}} \text { mass of sample after carbonation, } \mathrm{g} \\
& M_{\mathrm{CaCl}_{2}} \text { molar mass of } \mathrm{CaCl}_{2}, \mathrm{~g} / \mathrm{g} \cdot \mathrm{mol}
\end{aligned}
$$




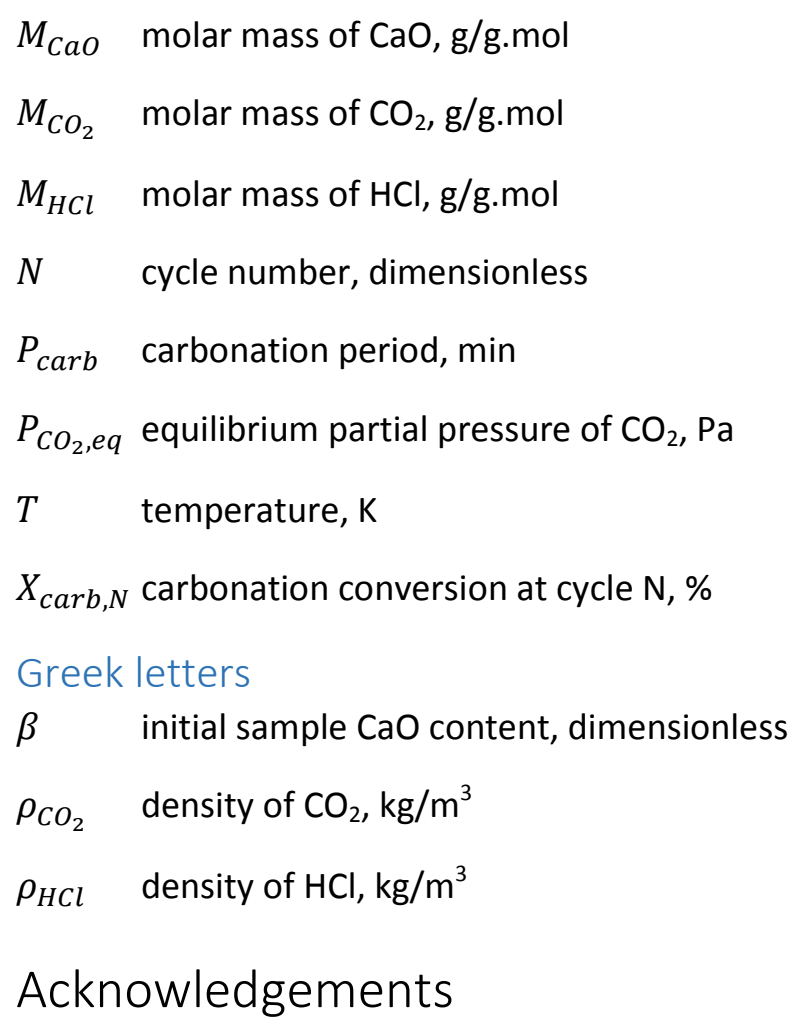

This research was sponsored and funded by the Program for Energy Research and Development (PERD) at Natural Resources Canada, Government of Canada.

\section{References}

Abanades, J. C., Grasa, G. S., Alonso, M., Rodriguez, N., Anthony, E. J., \& Romeo, L. M. (2007). Cost structure of a postcombustion $\mathrm{CO} 2$ capture system using $\mathrm{CaO}$. Environmental Science \& Technology, 41, 5523-5527.

Abanades, J. C., Rubin, E. S., \& Anthony, E. J. (2004). Sorbent costs and performance in CO2 capture systems. Industrial \& Engineering Chemistry Research, 43, 3462-3466.

Abu-Zahra, M. R., Schneiders, L. H., Niederer, J. P., Feron, P. H., \& Versteeg, G. F. (2007). $\mathrm{CO} 2$ capture from power plants: part I. A parametric study of the technical performance based on monoethanolamine. International Journal of Greenhouse Gas Control, 1(1), 3746.

Al-Jeboori, M. J., Nguyen, M., Dean, C., \& Fennell, P. S. (2013). Improvement of limestonebased $\mathrm{CO} 2$ sorbents for $\mathrm{Ca}$ looping by $\mathrm{HBr}$ and other mineral acids. Industrial \& Engineering Chemistry Research, 52, 1426-1433.

Arias, B., Abanades, J. C., Grasa, G. S., Manovic, V., \& Anthony, E. J. (2012). Effect of steam on the fast carbonation reaction rates of CaO. Ind. Eng. Chem. Res., 51(5), 2478-2482.

Arias, B., Cordero, J. M., Alonso, M., \& Abanades, J. C. (2012). Sulfation rates of cycled CaP particles in the carbonator of a Ca-looping cycle for postcombustion $\mathrm{CO} 2$ capture. American Institute of Chemical Engineers, 58, 2262-2269.

Arias, B., Grasa, G. S., \& Abanades, J. C. (2010). Effect of sorbent hydration on the average activity of $\mathrm{CaO}$ in a Ca-looping system. Chemical Engineering Journal, 163, 324-330. 
Arias, B., Grasa, G. S., Alonso, M., \& Abanades, J. C. (2012). Post-combustion calcium looping process with a highly stable sorbent activity by recarbonation. Energy \& Environmental Science, 5, 7353-7359.

Bale, C. W., Pelton, A. D., Thompson, W. T., Eriksson, G., Hack, K., \& Chartrand, P. (2014). FactSage 6.4. Retrieved from http://www.factsage.com

Ball, R. (2014). Entropy generation analyses of Endex and conventional calcium looping processes for CO2 capture. Fuel, 127, 202-211.

Barker, R. (1973). The reversibility of the reaction $\mathrm{CaCO} 3=\mathrm{CaO}+\mathrm{CO} 2 . \mathrm{J}$. Appl. Chem. Biotechnol, 23, 733.

Bie, R., Li, S., \& Yang, L. (2005). Reaction mechanism of $\mathrm{CaO}$ with $\mathrm{HCl}$ in incineration of wastewater in fluidized bed. Chemical Engineering Science, 60, 609-16.

Blamey, J., Anthony, E. J., Wang, J., \& Fennell, P. (2010). The calcium looping cycle for largescale CO2 capture. Progress in Energy and Combustion Science, 36, 260-279.

Blamey, J., Lu, D. Y., Fennell, P. S., \& Anthony, E. J. (2011). Reactivation of CaO-Based Sorbents for $\mathrm{CO} 2$ Capture: Mechnism for the Carbonation of $\mathrm{Ca}(\mathrm{OH}) 2$. Industrial \& Engineering Chemistry Research, 50, 10329-10334.

Boot-Handford, M. E., Abanades, J. C., Anthony, E. J., Blunt, M. J., Brandani, S., MacDowell, N., . . Fennell, P. S. (2014). Carbon capture and storage update. Energy and Environmental Science.

Borgwardt, R. H. (1970). Kinetics of the reaction of SO2 eith calcined limestone. Environmental Science \& Technology, 4, 59-63.

Champagne, S., Lu, D. Y., Macchi, A., Symonds, R. T., \& Anthony, E. J. (2012). Influence of steam injection during calcination on the reactivity of $\mathrm{CaO}$-based sorbent for carbon capture. Ind. Eng. Chem. Res., 52. 2241-2246.

Champagne, S., Lu, D. Y., Symonds, R. T., Macchi, A., \& Anthony, E. J. (2016). The effect of steam addition to the calciner in a calcium looping pilot plant. Powder Technology, 290, 114-123.

Chen, H. C., Zhao, C. S., Yang, Y. M., \& Zhang, P. P. (2012). CO2 capture and attrition performance of $\mathrm{CaO}$ pellets with aluminate cement under pressuirized carbonation. Applied Energy, 91, 334-40.

Chin, T., Yan, R., \& Liang, D. T. (2005). Study of the reaction of lime with HCl under simulated flue gas conditions using X-ray diffraction characterization and thermodynamic predictions. Industrial \& Engineering Chemistry Research, 44, 8730-8738.

Chrissafis, K. (2007). Multicyclic study on the carbonation of $\mathrm{CaO}$ using different limestones. $J$ Therm Anal Calorim, 89, 525-529.

Chyang, C. S., Han, Y. L., \& Zhong, Z. C. (2009). Study of $\mathrm{HCl}$ absorption by $\mathrm{CaO}$ at high temperature. Energy \& Fuels, 23, 3948-3953.

Davidson, J. F., Clift, R., \& Harrision, D. (1985). Fluidization, 2nd ed. New York: Academic Press.

Dean, C. C., Blamey, J., Florin, N. H., Al-Jeboori, M. J., \& Fennell, P. S. (2011). The calcium looping cycle for $\mathrm{CO} 2$ capture form power generation, cement manufacture and hydrogen production. Chemical Engineering Research and Design, 89, 836-855.

Dean, C. C., Dugwell, D., \& Fennell, P. S. (2011). Investigations into potential synergy between power generation, cement manufacture and $\mathrm{CO} 2$ abatement using the calcium looping cycle. Energy \& Environmental Science, 4, 2050-2053. 
Dou, B. L., Song, Y. C., Liu, Y. G., \& Feng, C. (2010). High temperature CO2 capture using calcium oxide sorbent in a fixed-bed reactor. J. Hazard. Mater., 183 (1-3), 759-765.

Duo, W., Kirkby, N. F., Seville, J. P., Kiel, J. H., Bos, A., \& Den Uil, H. (1996). Kinetics of HCl reactions with calcium and sodium sorbents for IGCC fuel gas cleaning. Chemical Engineering Science, 51, 2541-2546.

Elwell, L. C., \& Grant, E. S. (2006). Technology options for capturing CO2 - Special reports. Power, 150(8).

Fauth, D., Frommell, E. A., Hoffman, J. S., Reasbeck, R. P., \& Pennline, H. W. (2005). Eutectic salt promoted lithium zirconate: Novel high temperature sorbent for $\mathrm{CO} 2$ capture. Fuel Process. Technol., 86, 1503-1521.

Fennell, P. S., Davidson, J. F., Dennis, J. S., \& Hayhurst, A. N. (2007). Regeneration of sintered limestone sorbents for the sequestration of $\mathrm{CO} 2$ from combustion and other systems. Journal of the Energy Institute, 80, 116-119.

Fennell, P., \& Anthony, B. (2015). Calcium and Chemical Looping Technology for Power Generation and Carbon Dioxide(CO2) Capture. Cambridge, UK: Elsevier.

Freidina, E. B., \& Fray, D. J. (2000). Phase diagram of the system $\mathrm{CaCl}$-CaCO3. THermochim Acta, 351, 107-108.

Garcia-Lablano, F., Abad, A., de Diego, L. F., Gayan, P., \& Adanez, J. (2002). Calcination of calcium-based sorbents at pressure in a broad range of $\mathrm{CO} 2$ concentrations. Chemical Engineering Science, 57, 2381-2393.

Goto, K., Yogo, K., \& Higashii, T. (2013). A review of efficiency penalty in a coal-fired power plant with post-combustion CO2 capture. Applied Energy, 111, 710-720.

Grasa, G. S., \& Abanades, J. C. (2006). CO2 capture capacity of $\mathrm{CaO}$ in long series of carbonation/calcination cycles. Industrial and Engineering Chemistry Research, 45, 8846-8851.

Grasa, G. S., Abanades, J. C., Alonso, M., \& Gonzalez, B. (2008). Reactivity of highly cycled particles of $\mathrm{CaO}$ in a carbonation/calcination loop. Chemical Engineering Journal, 137, 561-567.

Hack, H., Alvarez, I., Diego, R., Lupion, M., Cortes, V., Hotta, A., . . Alvarez, J. (2012). Initial operation of the CIUDEN oxy-CFB boiler demonstration project. The 11th Annual Carbon Capture, Utilization \& Sequestration Conference. Pittsburgh, USA.

Hjornhede, A., Sotkovszki, P., \& Nylund, A. (2006). Erosion-corrosion of laser and thermally depsosited coatings exposed in fluidized bed combustion plants. Materials and Corrosion, 57 (4), 307-322.

Hughes, R. W., Lu, D., Anthony, E. J., \& Wu, Y. (2004). Improved long-tern conversion of limestone-derived sorbents for in situ capture of $\mathrm{CO} 2$ in a fluidized bed combustor. Industrial \& Engineering Chemistry Research, 43, 5529-5539.

IEA. (2010). Energy technology perspectives 2010: Scenarios and strategies to 2050. Paris: IEA.

IEA. (2014). Energy technology perspectives 2014 factsheet - 'Electricty storage as a game changer'. IEA.

Kierzkowska, A. M., Pacciani, R., \& Muller, C. R. (2013). CaO-based CO2 sorbents: from fundamentals to the development of new, highly effective materials. Chemistry \& Sustainability, Energy \& Materials, 6(7), 1130-1148.

Lara, Y., Lisbona, P., Martinez, A., \& Romeo, L. M. (2013). Design and analysis of heat exchanger networks for integrated Ca-looping systems. Applied Energy, 111, 690-700. 
Lawrence, A. D., \& Bu, J. (2000). The reactions between Ca-based solids and gases representative of those found in a fluidized-bed incinerator. Chemical Engineering Science, 55, 6129-6137.

Lowell, S., Thomas, M. A., \& Thommes, M. (2004). Characterization of porous solids and powders: surface area, pore size, and density. The Netherlands: Kluwer Academic Publishers.

Lysikov, A. I., Salanov, A. N., \& Okunev, A. G. (2007). Change of CO2 carrying capacity of $\mathrm{CaO}$ in isothermal recarbonation-decompostion cycles. Industrial and Engineering Chemistry Research, 46, 4633-4638.

MacKenzie, A., Granatstein, D. L., Anthony, E. J., \& Abanades, J. C. (2007). Economics of CO2 capture using the calcium cycle with a pressurized fluidized bed combustor. Energy \& Fules, 21, 920-926.

Manovic, V., \& Anthony, E. J. (2007). Steam reactivation of spent CaO-based sorbent from multiple CO2 capture cycles. Environmental Science \& Technology, 41, 1420-1425.

Manovic, V., \& Anthony, E. J. (2008). Parametric study on the CO2 capture capacity of CaObased sorbents in looping cycles. Energy \& Fuels, 22, 1851-1857.

Manovic, V., \& Anthony, E. J. (2008). Thermal activation of CaO-based sorbent and selfreactivation during $\mathrm{CO} 2$ capture looping cycles. Environmental Science \& Technology, 42, 4170-4174.

Manovic, V., \& Anthony, E. J. (2010). Carbonation of CaO-Based Sorbents Enhanced by Steam Addition . INd. Eng. Chem. Res., 49, 9105-9110.

Martinez, A., Lara, Y., Lisbona, P., \& Romeo, L. M. (2012). Energy penalty reduction in the calcium looping cycle. International Journal of Greehouse Gas Control, 7, 74-81.

Pachauri, R. K., \& Reisinger, A. (2007). Climate Change 2007: Synthesis Report. Contribution of Working Groups I, II and III to the Fourth Assessment Report of the Intergovernmental Panel on Climate Change. Intergovernmental Panel on Climate Change (IPCC). Geneva, Switzerland.

Partanen, J., Backman, P., Backman, R., \& Hupa, M. (2003). Formation of calcium chloride and its interaction with the sand particles during fluidised bed combustion. 17th international conference on FBC. Jacksonville, FL.

Partanen, J., Backman, P., Backman, R., \& Hupa, M. (2005). Absorption of HCl by limestone in hot flue gases. Part III: simultaneous absorption with SO2. Fuel, 84, 1685-1694.

Pradyot, P. (2003). Handbook of Inorganic Chemicals. New York: The McGraw-Hill Companies Inc.

Resnik, K. P., Yeh, J. T., \& Pennline, H. W. (2004). Aqua ammonia process for simultaneous removal of CO2, SO2, and NOx. Inter. J. Environ. Technol. Management, 4, 89-104.

Ridha, F. N., Lu, D. Y., Symonds, R. T., \& Champagne, S. (2016). Attrition of CaO-based pellets in a $0.1 \mathrm{MWth}$ dual fluidized bed pilot plant for post-combustion $\mathrm{CO} 2$ capture. Powder Technology, 291, 60-65.

Rodriguez, N., Alonso, M., Grasa, G. S., \& Abanades, J. C. (2008). Heat requirements in a calciner of $\mathrm{CaCO} 3$ integrated in a $\mathrm{CO} 2$ capture system using $\mathrm{CaO}$. Chemical Engineering Journal, 138, 148-154.

Rodriguez, N., Murillo, R., \& Abanades, J. C. (2012). CO2 capture from cement plants using oxyfired precalcination and/or calcium looping. Environmental Science \& Technology, 46, 2460-2466. 
Romeo, L. M., Catalina, D., Lisbona, P., Lara, Y., \& Martinez, A. (2011). Reduction of greehouse gas emissions by integration of cement plants, power plants, and $\mathrm{CO} 2$ capture systems. Greenhouse Gases: Science and Technology, 1, 72-82.

Ryden, M., \& Lyngfelt, A. (2006). Using steam reforming to porduce hydrogen with carbon dioxide capture by chemical-looping combustion. International Journal of Hydrogen Energy, 31, 1271-1283.

Sanchez-Biezma, A., Paniagua, J., DIaz, L., Lorenzo, M., Alvarez, J., Martinez, D., . . . Abanades, J. C. (2013). Testing postcombustion CO2 capture with $\mathrm{CaO}$ ub a $1.7 \mathrm{MWt}$ pilot facility. Energy Procedia, 37, 1-8.

Shimizu, T., Hirama, T., Hosoda, H., Kitano, K., Inagaki, M., \& Tejima, K. (1999). A twin fluidbed reactor for removal of $\mathrm{CO} 2$ from combustion processes. Chemical Engineering Research and Design, 77(A1), 62-68.

Silaban, A., \& Harrison, D. P. (1995). High-temperature capture of carbon dioxide: characteristics of the reversible reaction between $\mathrm{CaO}(\mathrm{s})$ and $\mathrm{CO} 2(\mathrm{~g})$. Chem. Eng. Commun, 137, 177.

Sun, P., Grace, J., Lim, C. J., \& Anthony, E. J. (2006). Removal of CO2 by calcium-based sorbents in the presence of SO2. Energy \& Fuels, 21, 163-170.

Sun, P., Lim, C. J., \& Grace, J. R. (2008). Cyclic CO2 capture by limestone-derived sorbent during prolonged calcination/carbonation cycling. AIChE J, 54, 1668-1677.

Sun, Z., Yu, F. C., Li, F., Li, S., \& Fan, L. S. (2011). Experimental study of $\mathrm{HCl}$ capture using $\mathrm{CaO}$ sorbents: activation, deactivation, reactivation, and ionic transfer mechanism. Industrial \& Engineering Chemsitry Research, 50, 6034-6043.

Suraniti, S. L., Nsakala, N. Y., \& Darling, S. L. (2009). Alsotn oxyfuel CFB boilers: A promising option for CO2 capture. Energy Procedia, 1, 543-548.

Symonds, R. T., Champagne, S., Firas, N., \& Lu, D. (2016). CO2 capture performance of CaObased pellets in a $0.1 \mathrm{MW}$ th pilot-scale calcium looping system. Powder Technology, 124-131.

Symonds, R. T., Lu, D. Y., Hughes, R. W., Anthony, E. J., \& Macchi, A. (2009). CO2 capture from simulated syngas via cyclic carbonation/calcination for a naturally occuring limestone: pilot-plant testing. Ind. Eng. Chem. Res., 48, 8431-8440.

Symonds, R. T., Lu, D. Y., Macchi, A., Hughes, R. W., \& Anthony, E. J. (2009). CO2 capture from syngas via cyclic carbonation/calcination for a naturally occurring limestone: Modelling and bench-scale testing. Chemical Engineering Science, 64, 3536-3543.

Tullin, C., \& Ljungstrom, E. (1989). Reaction between calcium carbonate and sulphur dioxide. Energy \& Fuels, 3, 284-287.

Valverde, J. M., Sanchez-Jimenez, P. E., \& Perez-Maqueda, L. A. (2014). Calcium-looping for post-combustion $\mathrm{CO} 2$ capture. On the adverse effect of sorbent regeneration under $\mathrm{CO} 2$. Applied Energy, 126, 161-171.

Wall, T., Stanger, R., \& Santos, S. (2011). Demonstrations of coal-fired oxy-fuel technology for carbon capture and storage and issues with commercial deployment. Int. J. Greenhouse Gas Control, 5, S5-S15.

Wang, J., Manovic, V., Wu, Y., \& Anthony, E. J. (2010). A study on the activity of CaO-based sorbents for capturing CO2 in clean energy processes. Applied Energy, 87, 1453-1458.

Wang, W., Li, Y., Xie, X., \& Sun, R. (2014). Effect of the presence of $\mathrm{HCl}$ on cyclic CO2 capture of calcium-based sorbent in calcium looping process. Applied Energy, 124, 246253. 
Yang, H., Xu, Z., Fan, M., Gupta, R., Slimane, R. B., Bland, A. E., \& Wright, I. (2008). Progress in carbon dioxide separation and capture: a review. J. Environ. Sci., 20(1), 14-27.

Yang, Y., Zhai, R., Duan, L., Kavosh, M., Patchigolla, K., \& Oakey, J. (2010). Integration and evaluation of a power plant with a $\mathrm{CaO}$-based $\mathrm{CO} 2$ capture system. International Journal of Greehouse Gas Control, 4, 603-612. 